\title{
The coordinating model of the Ganga Basin
}

\author{
M C CHATUR VEDI, PETER ROGERS* and SHYANG-LAI KUNG** \\ Applied Mechanics Department and Centre for Systems Engineering and Policy Studies, \\ Indian Institute of Technology, New Delhi 110016, India \\ - Department of Environmental Engineering, Harvard University, Pierce Hall, 121 \\ Cambridge, Massachusetts 02138, usA \\ ** Argonne National Laboratory, 9700, S Case Avenue, Argonne, Illinois 60439, usA
}

\begin{abstract}
A watract. A scheme of model studies required to analyse a complex large scale system through decomposition approach is outlined. First, the total system is proposed to be modelled to identify interlinkages of the subsystems. Then the subsystems are analysed in detail to develop response functions. Finally the optimal system functioning is obtained by modelling the entire system in terms of response functions of the components.

A linear programming model is developed for modelling the total system to identify the interlinkages. Its application is demonstrated in the Greater Ganga Basin using published data. Trade-off is developed between power generation and irrigated area in various seasons.
\end{abstract}

Keywords. Large scale systems; multilevel hierarchical approach; co-ordinating screening model; linear programming model

\section{Introduction}

Systems analysis of large systems is an integrated-hierarchial multilevel and multistage activity because of the complexity, scale and dynamic nature of the problem. Multilevel hierarchial analysis may be carried out in several ways (Lasdon 1970; Haimes 1977; Chaturvedi 1974). In the first instance, the total system may be modelled to identify the order of interlinkage of the sub-systems. In the second study, the sub-systems may be examined in detail and their response expressed as a function of the interlinkage over the likely range as anticipated from the first study. Finally, the optimal system functioning may be obtained by modelling the entire system in terms of the response functions of each of the sub-systems as obtained from the second study.

The type of model depends upon the characteristics, scale and complexity of the system, as well as on the objectives of the analysis. The first study carried out through a model called the coordinating-screening model is for coarse screening and deterministic modelling dividing the year into two or three time periods. A linearprogramming approach may be used. Further, by adapting the inflows over a range to cover the likely variability of inflows, the implications of the stochastic nature of inputs may be studied (Jacoby \& Loucks 1972; Chaturvedi \& Srivastava 1981). For the second series of models for sub-systems analysis, any appropriate systems analysis approach using deterministic and stochastic models may be used (Hall \& Dracup 1970; Biswas 1976; Chaturvedi 1984). And finally for the third-stage analysis, mathematical programming models and simulation models, singly or hierarchially, may be used. For studying the Ganga basin, the hierarchial modelling scheme shown in figure 1 was

A list of symbols is given at the end of the paper. 


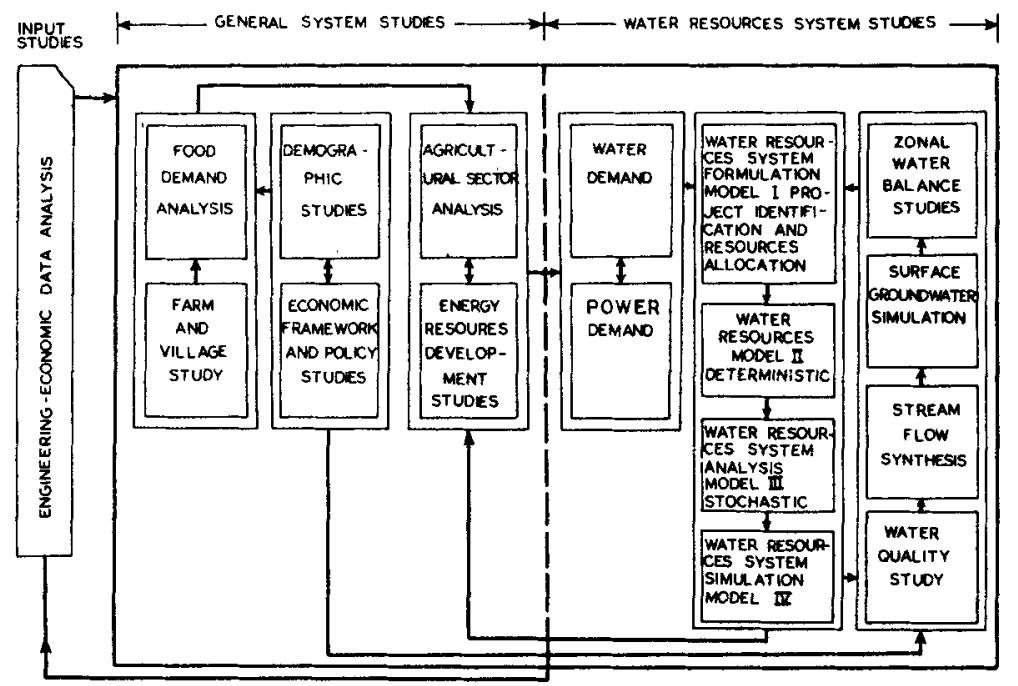

ITERATE THROUGH SENSITIVITY ANALYSIS TO REOUISITE DEGREE /REFINEMENT AND BALANCE

Figure 1 Water resources systems analysis modelling morphology

developed. The scheme with slight modifications has been applied to study the Punjab water resources (Chaturvedi 1979).

It must be emphasised at the outset that the study brings out only an approach to analysis and the quantitative figures given are meant only to illustrate the approach for the decomposition of the system and have no real life implication.

\section{The model}

The first stage preliminary screening of the Ganga basin is discussed in this section.

For the first coordinating-screening model, a simple linear model was constructed to coordinate all the demands placed upon the system (Chaturvedi 1974; Chaturvedi and Rogers 1975). This model is then used as a tool to explore the various goals to be attained and the constraints on development. Once the system has been fully explored by this inexpensive model, it can be broken up into smaller, more manageable pieces for more detailed analysis. However, the overall model can still be used to coordinate the results of the detailed studies as they become available, or the second coordination can be in terms of the response functions of each of the sub-systems.

Figure 2 shows the schematic layout of the Ganga basin used in the coordinating model. There are 49 river-schematic nodes of interest at which junctions, diversions, groundwater pumping and return flows occur. The model considers 5 storage reservoirs, 6 hydropower plants, and 25 major irrigation works as already developed and looks for the optimal allocation of the water resources for agriculture and power subject to meeting downstream flows for navigation, water supply and salinity control in the delta.

Table 1 summarises the system sketch and the water continuity relationships. The number in each row shows the connection and the flow direction for each of the parameters or division variables- $X$, river flow; $Y$, diversion; $Z$, diversion for irrigation; $P$, flow for hydroelectric generation; $V$, storage locations; $A$, area for irrigation; $T$, 


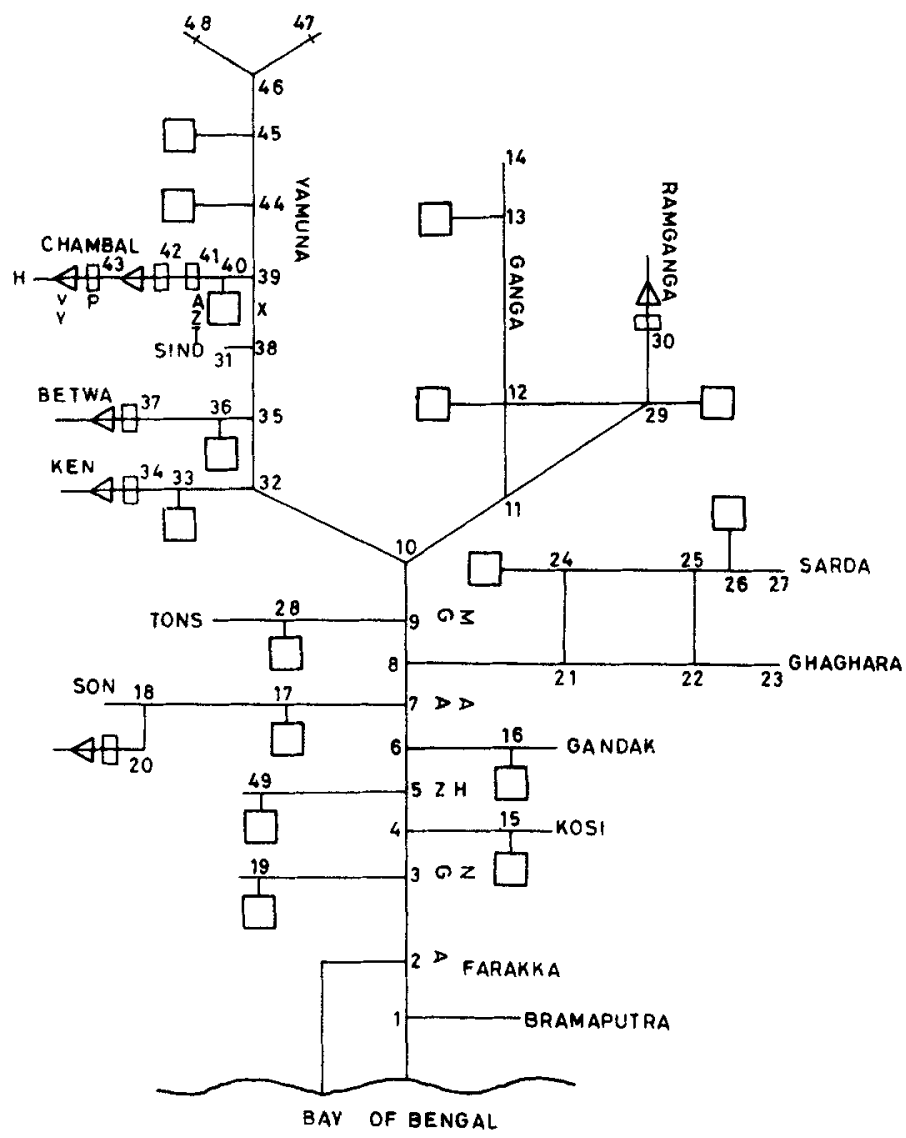

Figure 2. Schematic diagram of the Ganga basin

groundwater development; $D$, groundwater return flow; $H$, the hydrological input. For example, a negative number $(-k)$ from a row of node $i$ indicates that water flows from node $k$ towards node $i$. On the other hand, a positive number $(k)$ implies that water flows away from node $i$ towards node $k$.

\subsection{Objective function}

The major uses for water in the basin are to produce energy and for agriculture; therefore, the coordinating-screening model is formulated on the basis of these two uses. Other uses of water (such as water quality control, navigation, urban water supply, flood control, etc.) are not fully studied and are constrained by minimum or maximum river flows.

An objective function is thus constructed to include the major water uses for energy production and irrigation. This objective function will enable the model to select the best mix of these uses of water. The objective is to maximise agriculture and energy in the following form.

$$
\max Z=f_{a} \cdot \sum_{i} \sum_{j}\left(A_{i j}\right)+f_{p} \cdot \sum_{i} \sum_{i}\left(P_{i j} \cdot K_{i}\right)
$$


Table 1. System identification table.

\begin{tabular}{|c|c|c|c|c|c|c|c|c|c|}
\hline Node no. & $\mathbf{X}$ & $\mathbf{Y}$ & $\mathbf{Z}$ & $\mathbf{P}$ & $\mathbf{V}$ & $\mathbf{A}$ & $\mathbf{T}$ & D & $\mathbf{H}$ \\
\hline 1 & $1-2$ & & & & & & & -2 & 1 \\
\hline 2 & $2-3$ & 2 & 2 & & & 2 & 2 & -3 & \\
\hline 3 & $3-4-19$ & & 3 & & & 3 & 3 & $-4-19$ & \\
\hline 4 & $4-5-15$ & & 4 & & & 4 & 4 & $-5-15$ & \\
\hline 5 & $5-6-19$ & & 5 & & & 5 & 5 & $-6-19$ & 5 \\
\hline 6 & $6-7-16$ & & 6 & & & 6 & 6 & $-7-16$ & \\
\hline 7 & $7-8-17$ & & 7 & & & 7 & 7 & -17 & 7 \\
\hline 8 & $8-9-21$ & & & & & & & & 8 \\
\hline 9 & $9-10-28$ & & & & & & & -28 & 9 \\
\hline 10 & $10-11-32$ & & & & & & & -32 & \\
\hline 11 & $11-12-29$ & & & & & & & $-12-29$ & 11 \\
\hline 12 & $12-13$ & -29 & 12 & & & 12 & 12 & -13 & \\
\hline 13 & $13-14$ & & 13 & & & 13 & 13 & & \\
\hline 14 & 14 & & & & & & & & 14 \\
\hline 15 & 15 & & 15 & & & 15 & 15 & & 15 \\
\hline 16 & 16 & & 16 & & & 16 & 16 & & 16 \\
\hline 17 & $17-18$ & & 17 & & & 17 & 17 & & \\
\hline 18 & $18-20$ & & & & & & & & 18 \\
\hline 19 & 19 & & 19 & & & 19 & 19 & & 19 \\
\hline 20 & 20 & 20 & & 20 & 20 & & & & 20 \\
\hline 21 & $21-22-24$ & & & & & & & -24 & \\
\hline 22 & $22-23$ & 22 & & & & & & & \\
\hline 23 & 23 & & & & & & & & 23 \\
\hline 24 & $24-25$ & & 24 & & & 24 & 24 & & \\
\hline 25 & $25-26$ & -22 & & & & & & -26 & \\
\hline 26 & $26-27$ & & 26 & & & 26 & 26 & & · \\
\hline 27 & 27 & & & & & & & & 27 \\
\hline 28 & 28 & & 28 & & & 28 & 28 & & 28 \\
\hline 29 & $29-30$ & 29 & 29 & & & 29 & 29 & & \\
\hline 30 & 30 & 30 & & 30 & 30 & & & & 30 \\
\hline 31 & 31 & & & & & & & & 31 \\
\hline 32 & $32-33-35$ & & 32 & & & 32 & 32 & $-33-35$ & \\
\hline 33 & $33-34$ & & 33 & & & 33 & 33 & & \\
\hline 34 & 34 & 34 & & & & & & & 34 \\
\hline 35 & $35-36-38$ & & 35 & & & 35 & 35 & $-36-38$ & 35 \\
\hline 36 & $36-37$ & & 36 & & & 36 & 36 & & \\
\hline 37 & 37 & 37 & & 37 & 37 & & & & 37 \\
\hline 38 & $38-31-39$ & & 38 & & & 38 & 38 & & 38 \\
\hline 39 & $39-40-44$ & & & & & & & $-40 \cdot 44$ & 39 \\
\hline 40 & $40-41$ & & 40 & & & 40 & 40 & & \\
\hline 41 & $41-42$ & 41 & & 41 & & & & & \\
\hline 42 & $42-43$ & 42 & & 42 & 42 & & & & \\
\hline 43 & 43 & 43 & & 43 & 43 & & & & 43 \\
\hline 44 & $44-45$ & & 44 & & & 44 & 44 & -45 & 44 \\
\hline 45 & $45-46$ & & 45 & & & 45 & 45 & & 45 \\
\hline 46 & $46-47-48$ & & & & & & & & \\
\hline 47 & 47 & & & & & & & & 47 \\
\hline 48 & 48 & & & & & & & & 48 \\
\hline 49 & 49 & & 49 & & & 49 & 49 & & 49 \\
\hline
\end{tabular}


where $f_{a}$ is the net benefit of agriculture due to irrigation and $f_{p}$ is the net benefit of energy production.

\subsection{The constraints}

The constraints of the coordinating model are formulated according to system identification in table 1 and the schematic layout in figure 2. There are six major types of constraints, (i) hydrological constraints, (ii) agricultural constraints, (iii) capacity constraints, (iv) municipal water supply, (v) economic constraints, (vi) environmental constraints, and others. A complete description of the constraint set for each node is given in appendix $A$.

2.2a Hydrological constraints (i) Continuity constraints-a typical constraint of this kind will be

$$
X_{i j}+Z_{i j}=H_{i j}+X_{i+1, j}+D_{i+1, j}
$$

The amount of water that flows away from node $i$ (river flow $X_{i j}$, irrigation diversion $Z_{i j}$ ) equals the amount of water that flows towards node $i$ (river flow $X_{i+1, j}$, groundwater return $D_{i+1, j}$ and hydrological input $H_{i j}$ ).

(ii) Groundwater returns - a certain fraction $\left(\xi_{j}\right)$ of the unpumped groundwater is returned to the river at a downstream node,

$$
D_{i j}=\xi_{j}\left[\theta_{i} A G_{i}-\sum_{j} T_{i j}\right] .
$$

For example, at node $i$, the groundwater pumped in a year is $\Sigma_{j} T_{i j}$ and the amount of groundwater left is $\theta_{i} A G_{i}-\Sigma_{j} T_{i j}$, of which $\xi_{j}$ portion is returned to the river at a downstream node during the $j$ th period.

$2.2 \mathrm{~b}$ Agricultural constraints (i) Field irrigation requirements for each crop are provided by surface water and groundwater irrigation,

$$
T_{i j}+Z_{i j}=\alpha_{i j} A_{i j} \text {. }
$$

It is assumed for simplicity that the irrigation water is lost to the river system. This water is either evapotranspirated or percolated into the aquifer.

(ii) Culturable land and current irrigation level: irrigation cannot exceed the culturable land at each district and it should reach at least the current irrigation level,

$$
A L_{i} \leqslant A_{i j} \leqslant A H_{i}
$$

(iii) An artificial constraint is imposed in the model to make the summer season a land preparation season for the following kharif season (i.e., irrigated acreage at any district during the summer season equals that of the kharif season):

$$
A_{\text {i2 }}=A_{i 3} \text {, }
$$

where $A_{i 1}, A_{i 2}, A_{i 3}$ are areas irrigated in rabi, summer and kharif seasons respectively.

2.2c Capacity constraints (i) Irrigation channel: new capacity for irrigation channels at each agricultural district is provided in order to divert more surface water for irrigation. The increased channel capacity at node $i$ becomes $Z H_{i}+Z{ }_{\mathrm{NEW}_{i}}$,

$$
Z_{i j} \leqslant m_{j} \cdot\left(Z H_{i}+Z \mathrm{NEW}_{i}\right)
$$

where $m_{j}$ is the number of months during the $j$ th period. 
(ii) Groundwater storage: annual groundwater irrigation at any agricultural district cannot exceed the available groundwater storage at that district,

$$
\sum_{j} T_{i j} \leqslant \theta_{i} A G_{i}
$$

(iii) Diversion channel: the amount of water diverted cannot exceed the capacity of the channel,

$$
Y_{i j} \leqslant m_{j} \cdot Y H_{i} .
$$

(iv) Reservoir live storage: The reservoir cannot store more water than its live storage capacity during any period of time,

$$
V_{i j} \leqslant V H_{i} \text {. }
$$

(v) Hydropower plant capacity: The water that drives the turbine cannot exceed the generating capacity. New turbines can be installed for necessary expansion of the power plant,

$$
P_{i j} \leqslant m_{j}\left(P H_{i}+P \text { NEW }_{i}\right) \text {. }
$$

2.2d Municipal water supply Water is diverted from the Ganga to meet the municipal water demand at Calcutta,

$$
Y_{i j} \geqslant m_{j} \cdot Y L_{i} \text {. }
$$

2.2e Economic constraint Power demand distribution: the energy generated during each period must satisfy the distributional demand $\left(\eta_{j}\right)$,

$$
\sum_{i}\left(P_{i j} \cdot K_{i}\right) \geqslant \eta_{j} \sum_{j} \sum_{i}\left(P_{i j} \cdot K_{i}\right)
$$

2.2f Environmental and other constraints In order to maintain river flows for navigation, water quality control, irrigation requirements downstream and other purposes, several minimum flows are provided,

$$
X_{i j} \geqslant m_{j} \cdot X L_{i}
$$

\section{Data used}

Input data of the coordinating-screening model contains hydrological inputs $\left(H_{i j}\right)$, field irrigation requirement given in appendix $\mathrm{B}\left(\alpha_{i j}\right)$, culturable land $\left(A H_{i}\right)$, low flow requirement $\left(X L_{i}\right)$, groundwater availability $\left(\theta_{i} A G_{i}\right)$, fractions of groundwater return $\left(\xi_{j}\right)$, reservoir live storage $\left(V H_{i}\right)$, hydropower plant capacity $\left(P H_{i}\right)$, power conversion factor $\left(K_{i}\right)$, and power demand distribution $\left.\eta_{j}\right)$.

\subsection{Hydrological input}

Since the model is deterministic, the hydrology of a typical single year is required. For flood protection and other purposes, a hydrology of extreme events which would have a chance of realization of one year out of every 50 or 100 years may be more appropriate. The hydrological inputs $\left(H_{i j}\right)$ at various nodes are given in table 2 . This table is constructed according to the estimated average monthly flows in the sub-basins of the Ganga by Briscoe (1974). 
Table 2. Hydrological inputs (m cu m/season)

\begin{tabular}{|c|c|c|c|}
\hline Node no & Rabi & Summer & Kharif \\
\hline 1 & 80561 & 43891 & 346812 \\
\hline 5 & & 680 & 12925 \\
\hline 7 & & 773 & 14694 \\
\hline 8 & & 1814 & 34474 \\
\hline 9 & & 421 & 7995 \\
\hline 11 & & 636 & 12092 \\
\hline 35 & & 188 & 3580 \\
\hline 38 & & 188 & 3580 \\
\hline 39 & & 188 & 3580 \\
\hline 44 & & 471 & 8949 \\
\hline 45 & & 471 & 8949 \\
\hline 14 & 3823 & 3330 & 22806 \\
\hline 15 & 6501 & 8030 & 37461 \\
\hline 16 & 1052 & 350 & 14838 \\
\hline 18 & 8338 & 7229 & 53410 \\
\hline 19 & 259 & 57 & 931 \\
\hline 20 & 688 & 229 & 9697 \\
\hline 23 & 5551 & 4785 & 32928 \\
\hline 27 & 5551 & 4785 & 32928 \\
\hline 28 & 370 & 123 & 5217 \\
\hline 30 & 764 & 654 & 4489 \\
\hline 31 & 575 & 194 & 8236 \\
\hline 34 & 575 & 194 & 8236 \\
\hline 37 & 575 & 194 & 8236 \\
\hline 43 & 2506 & 777 & 32984 \\
\hline 47 & 936 & 809 & 5569 \\
\hline 48 & 936 & 809 & 5569 \\
\hline 49 & 259 & 57 & 931 \\
\hline
\end{tabular}

Total:

(1) Include Brahmaputra (node)

$\begin{array}{lll}\text { Rabi } & \text { Summer } & \text { Kharif } \\ 119620 & 182327 & 742096 \\ 1044043 \mathrm{~m} \mathrm{cu} \mathrm{m} \text { m/year. } & \end{array}$

(2) Exclude Brahamaputra (node)

$\begin{array}{lll}\text { Rabi } & \text { Summer } & \text { Kharif } \\ 39059 & 38436 & 395284 \\ 472779 & \mathrm{~m} \text { cu m/year. } & \end{array}$

\subsection{Field irrigation requirements}

Monthly field irrigation requirements $\left(\alpha_{i j}\right)$ are estimated as per crop, rainfall, temperature, wind, humidity, sunshine, solar radiation and other factors at each agricultural district. These monthly requirements are then aggregated into three seasons for the simplified three-season model: (a) rabi season (November, December, January, February and March); (b) summer season (April, May and June); and (c) kharif season (July, August, September and October). Field irrigation requirements for different seasons at various agricultural districts are presented in table 3 . 
Talk 3. Field irrigation requirements at various districts (Seasonal)-(meter/unit area)

\begin{tabular}{|c|c|c|c|c|c|}
\hline Node no & $A_{\max }$ & $A_{\min }$ & Rabi & Summer & Kharif \\
\hline 2 & 6600 & 660 & 0.5860 & 0.0510 & 0.3300 \\
\hline 3 & 6600 & 660 & 06200 & $0-1310$ & $0-3800$ \\
\hline 4 & 1900 & 190 & $0-6200$ & 0.1310 & 0.3800 \\
\hline 5 & 1900 & 190 & 0.6200 & 0.1310 & 0.3800 \\
\hline 6 & 2600 & 260 & 06200 & 0.1310 & $0-3800$ \\
\hline 7 & 3000 & 300 & 0.6200 & 0.1310 & 0.3800 \\
\hline 12 & 24000 & 2400 & 0.5490 & 0.2730 & 0.5720 \\
\hline 13 & 20000 & 2000 & 0.5210 & 0.2150 & 0.5340 \\
\hline 15 & 19000 & 1900 & 0.6200 & 0.1310 & 0.3800 \\
\hline 16 & 19000 & 1900 & 06200 & 0.1310 & 0.3800 \\
\hline 17 & 33000 & 3300 & 0.6340 & 0.1430 & $0-3700$ \\
\hline 19 & 26100 & 2610 & $0-6610$ & 0.1390 & 0.3950 \\
\hline 24 & 40000 & 4000 & 0.6140 & 0.1990 & $0-5020$ \\
\hline 26 & 36800 & 3680 & 0.6140 & 0.1990 & 0.5020 \\
\hline 28 & 19000 & 1900 & 0.6490 & $0-1400$ & 0.3750 \\
\hline 29 & 20800 & 2080 & 0.4920 & $0-2250$ & 0.4820 \\
\hline 32 & 20000 & 2000 & 0.6220 & 0.1960 & 0.5140 \\
\hline 33 & 3100 & 310 & 0.6450 & $0-1610$ & $0-4560$ \\
\hline 35 & 20000 & 2000 & 0.6220 & $0-1960$ & 0.5140 \\
\hline 36 & 4700 & 470 & 0.6450 & $0-1610$ & 0.4560 \\
\hline 38 & 20000 & 2000 & $0-6220$ & $0-1960$ & 0.5140 \\
\hline 40 & 100000 & 5000 & 0.6360 & $0-2280$ & 0.7240 \\
\hline 44 & 50000 & 2000 & 0.5320 & 0.2690 & 1.039 \\
\hline 45 & 50000 & 2000 & 0.5100 & 0.2440 & 0.7800 \\
\hline 49 & 26100 & 2610 & 0.6610 & $0-1390$ & 0.3950 \\
\hline
\end{tabular}

\subsection{Culturable land and current irrigation level}

Information about culturable land at each agriculture district is reported by the Irrigation Commission (1972). Table 3 also gives the culturable land districtwise. The current irrigation level has been assumed at $10 \%$ of the culturable land in most districts.

\subsection{Current irrigation capacity}

Table 4 lists some capacities of irrigation channels as recorded in the Irrigation Commission (1972). New capacity $\left.\left(Z_{N^{\prime}}\right)_{i}\right)$ is constructed in the coordinating model to allow more surface water diversion for irrigation.

\subsection{Groundwater storage}

Groundwater storage at an agriculture district is the product of annual groundwater availability $\left(\theta_{i}\right)$ and area $\left(A G_{i}\right)$ over which groundwater is available. Aquifer is assumed to be fully recharged annually. These groundwater storages are given in table 5

\subsection{Reservoir live storage, hydro-power plant capacity, and power conversion factor}

Figures of reservoir live storages, current power plant capacities, and power conversion factors are presented in table 6. Although preliminary study indicates that there is a 
Table 4. Current channel capacities

\begin{tabular}{lccc}
\hline Node no & mcum/mon & Node no & mcum/mon \\
\hline $2-7$ & - & 29 & $5 \cdot 7$ \\
12 & $155 \cdot 7$ & 32 & - \\
13 & $297 \cdot 5$ & 33 & $56 \cdot 6$ \\
15 & $283 \cdot 2$ & 35 & - \\
16 & $311 \cdot 5$ & 36 & $85 \cdot 0$ \\
17 & $283 \cdot 2$ & 38 & - \\
19 & 28.3 & 40 & 260.5 \\
24 & $283 \cdot 2$ & 44 & 90.6 \\
26 & 396.4 & 45 & 424.8 \\
28 & 28.3 & 49 & 28.3 \\
\end{tabular}

Table 5. Groundwater availability

\begin{tabular}{lrrrlr}
\hline Node no & m cu m & Node no & mcu m & Node no & m cu m \\
\hline 2,3 & 2255 & 15 & 6462 & $32,35,38$ & 2987 \\
4,5 & 677 & 16 & 4454 & 33 & 579 \\
6 & 902 & 17 & 11659 & 36 & 877 \\
7 & 621 & 19 & 11277 & 40 & 23816 \\
12 & 7467 & 24 & 8960 & 44,45 & 2987 \\
13 & 2987 & 26 & 4480 & 49 & 10600 \\
& & 28 & 2838 & & \\
& 29 & 3734 & & \\
\hline
\end{tabular}

Total groundwater capacity: $122512 \mathrm{mcum}$.

Table 6. Power conversion factors, power plant capacities and reservoir live storages.

\begin{tabular}{llcc}
\hline Node no. & $K=\frac{M W}{\text { m cum/month }}$ & $P H(M W)$ & $V H$ (m cum) \\
\hline 20 & 0.1816 & 195 & 10608 \\
30 & 0.2270 & 130 & 2220 \\
37 & 0.0454 & 13 & 780 \\
41 & 0.0272 & 64 & \\
42 & 0.0908 & 111 & 1567 \\
43 & 0.1090 & 75 & 6920 \\
\hline
\end{tabular}

reservoir and a power plant at node 34 (KEN), they are removed from the model because they are not reported in the Irrigation Commission (1972). Appropriate new power plant capacity $\left(P \mathrm{NEW}_{i}\right)$ may be installed in order to attain higher energy production. Power production factor $\left(K_{i}\right)$ is calculated by using a head of one half dam height.

\subsection{Power demund distribution}

Distributional constraints may be imposed on the energy production so that the energy output meets the monthly or seasonal demand $\left(\eta_{j}\right)$. Initial values of the demand 
distribution are taken at $0.0955,0.0797,0.0762,0.0515,0.0630,0.0784,0.0797,0.0797$, $0.0938,0.1233,0.1039$, and 0.0753 for the respective twelve months. These distributions should be reevaluated according to the power requirements for groundwater pumping and other irrigation facilities.

\subsection{Other water demands}

Water uses such as water quality control, navigation, and other purposes are not well developed. These water uses are considered in the model as minimum river flows and are presented in table 7 .

\section{Matrix Generation}

The coordinating-screening model described above is a form of linear program and can be solved by IBM/MPSX. The matrix preparation for this IBM/MPSX used in Italy on the Tiber River Basin by Rogers \& Chi (1973) is employed to generate the matrix of the Ganga Basin in the MPSX input format. The Ganga Basin linear program for a simplified three-season model consists of $\mathbf{4 9 0}$ constraint rows of which most are continuity equations, about 1050 decision variables and 3500 non-zero matrix elements.

\section{Solutions}

In this simplified three-season model solutions using various assumptions have been obtained. In each solution the summer season (June irrigation) is assumed to be land preparation and the model is constrained so that the area under irrigation during the summer season at each district must also be irrigated in the kharif season. In most solutions energy is maximized subject to different constraint sets.

\subsection{Solution 1}

Maximizing energy under current power plant capacity,

$$
\max Z=f_{P} \cdot \sum_{j} \sum_{i}\left(P_{i j} \cdot K_{i}\right)
$$

In this solution, energy production is unrestricted by the distributional constraints. The maximum energy under the current generating capacity is $55,863 \mathrm{GWh}$

Table 7. Low flow requirements.

\begin{tabular}{lc}
\hline Node no. & $X L$ (m cu m/month) \\
\hline 2 & 100 \\
5 & 50 \\
7 & 240 \\
9 & 285 \\
10 & 255 \\
44 & 38 \\
45 & 180 \\
\hline
\end{tabular}


$(19,876 \mathrm{GWh}$ in rabi season, $15,427 \mathrm{GWh}$ in summer season, and $20,560 \mathrm{GWh}$ for kharif season; which are $35 \%, 28 \%$ and $37 \%$ respectively). Compared with the installed capacity $(95,093 \mathrm{GWh} /$ year $),{ }^{*}$ hydropower facilities are about $60 \%(55 \cdot 863 / 95 \cdot 093)$ utilized.

The energy output of the system is limited by water availability at power plant nodes 20 and 30 (Ramganga). On the other hand, the installed turbine capacities and reservoir storage capacities have restricted the energy production at power plant nodes 37 (Betwa), 41, 42 and 42 (Chambal) where large quantity of water is bypassed from reservoirs through diversion channels.

\subsection{Solution 2}

Maximizing energy with new power plant capacities,

$$
\max Z=f_{P} \cdot \sum_{j} \sum_{i}\left(P_{i j} \cdot K_{i}\right)
$$

If new turbines are installed when necessary, the energy production reaches 103, 932 GWh ignoring the distributional constraints**. All hydrological inflow upstream of power plants are utilized for energy.

New capacity is not needed at nodes 20 (Rihand) and 30 (Ramganga) since they are restricted by the availability of hydrological inputs. The system requires new turbines at nodes 37 (Betwa), 41, 42 and 43 (Chambal). These additional capacities ${ }^{* * *}$ are $72 \mathrm{MW}$ at node 37, $103 \mathrm{MW}$ at node $41,445 \mathrm{MW}$ at node 42 and $635 \mathrm{MW}$ at node 43 . When new turbines are installed, the energy production will only be limited by the hydrological inputs. However, excessive new capacities are required at these power plants (nodes 37, 41,42 and 43 ) due to the extremely high kharif season inflows, which the reservoirs cannot regulate.

The annual irrigated acreage under this scheme reaches $56.8 \mathrm{~m}$ ha $(17.2 \mathrm{~m}$ ha in rabi season and $39.6 \mathrm{~m}$ ha in the kharif season). This irrigation level is also the maximum area that can be fully irrigated under the current constraints.

\subsection{Solution 3}

Maximizing energy subject to various levels of irrigation, while energy output also meets the distributional constraints,

$$
\max Z=f_{p} \cdot \sum_{j} \sum_{i}\left(P_{i j} \cdot K_{i}\right)
$$

Since energy and irrigation are the major water uses in the model, it is useful to understand how these two interact with each other. For this purpose, energy is maximized according to demand distribution subject to different levels of irrigation usage.

\footnotetext{
* This is the installed hydropower capacity at $65 \%$ load factor.

** If energy production must satisfy demand distribution, then the energy output will only reach 74,172 GWh even when new turbines are installed.

*** The new installed turbines have capacities at $110,158,685$ and $977 \mathrm{MW}$ for power plants at nodes 37,41 , 42 and 43 respectively at a $65 \%$ load factor.
} 
To facilitate the solution, the power distributional constraints are formulated in the following form:

$$
\sum_{i}\left(P_{i j} K_{i}\right) \geqslant \eta_{j} \cdot \sum_{j} \sum_{i}\left(P_{i j} K_{i}\right)
$$

where distribution values of $\eta_{j}$ are subject to adjustment to simulate real demands.

With an irrigation level lower than $55 \mathrm{~m}$ ha $(15.9 \mathrm{~m}$ ha in the rabi season, $39.1 \mathrm{~m}$ ha in the kharif season) the energy output reaches a maximum level at $54,254 \mathrm{GWh}$ $(23,362 \mathrm{GWh}$ in rabi, $10,465 \mathrm{GWh}$ in summer and $20,427 \mathrm{GWh}$ in kharif.) On the other hand, when energy production is less than $36,461 \mathrm{GWh}(15,700 \mathrm{GWh}$ in rabi, $7,033 \mathrm{GWh}$ in summer and $13,728 \mathrm{GWh}$ in kharif), the irrigation level is maximized at $56.8 \mathrm{~m}$ ha (17.2 $\mathrm{m}$ ha in rabi and $39.6 \mathrm{~m}$ ha in kharif). It is not possible to generate energy higher than $54,254 \mathrm{GWh}$ by sacrificing irrigation and it is not feasible to insist on an irrigation level higher than $56.8 \mathrm{~m}$ ha by giving up energy production. For any level of irrigation between these two extremes ( 55 and $56.8 \mathrm{~m} \mathrm{ha}$ ), there is a corresponding energy production (between 36,461 and $54,254 \mathrm{GWh}$ ). No further parametric study on energy and irrigation in these ranges is made since the difference between the two irrigation levels is relatively small. Solutions of these two extremes are shown in figure 3.

Any point inside the boundary $A B C D$ is feasible but not efficient. Furthermore, points between $A$ and $B$ are not efficient because the irrigation level can be increased from zero to $55 \mathrm{~m}$ ha without any loss of energy. Similarly, points between $C$ and $D$ are not efficient. Points that fall on the line $B C$ denote the production frontier. Point $C$ represents operating the system for agricultural maximization and treating energy as a residual. The marginal rate of transformation of energy for agriculture at any point on the line $B C$ is the gradient of the line segment $B C$. This rate is estimated at

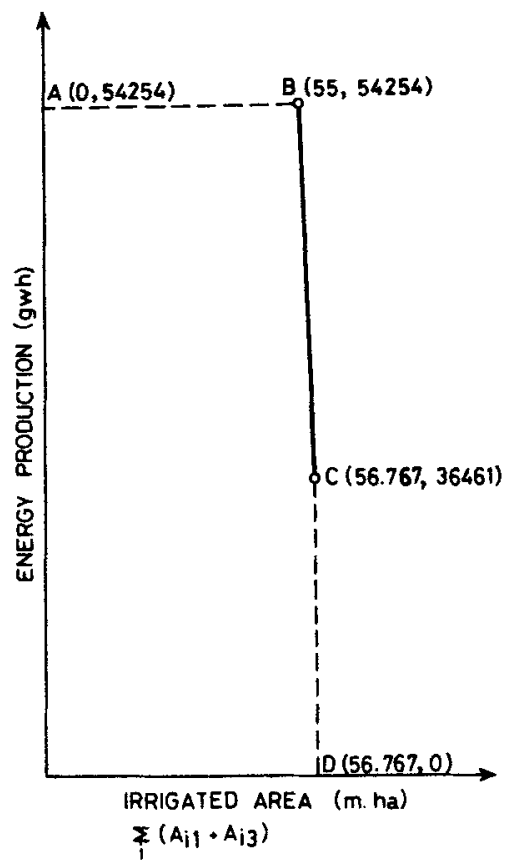

Figure 3. Trade-off between energy and total irrigation 
$-10,070 \mathrm{GWh} / \mathrm{m}$ ha (i.e., to gain $1 \mathrm{~m}$ ha of irrigation between points $B$ and $C$ $10,070 \mathrm{GWh}$ energy is sacrificed).

The range of irrigated acreage is only $1.8 \mathrm{~m}$ ha $(56.8-55)$ while energy production has a relatively wide range (from 36,461 to $54,254 \mathrm{GWh}$ ) of variation. No substantial irrigation can be gained by giving up energy production (at a rate of $10,070 \mathrm{GWh}$ for only $1 \mathrm{~m} \mathrm{ha}$ ).

Irrigated acreage is at capacity level at most downstream districts where water is available through accumulation of inflows. Reservoirs are full in the kharif season to regulate the excessive monsoon water for irrigation in the following rabi season.

\subsection{Solution 4}

Trade-off between rabi irrigation and kharif irrigation,

$$
\max Z=\sum_{i} A_{i 3}, \text { subject to various levels of } \sum_{i} A_{i 1} .
$$

Since the reservoirs and groundwater storage can regulate the water for irrigation from one season to the next, there is a definite trade-off between rabi irrigation and kharif irrigation. Solutions (points $B, C, D, E, F, G$ and $H$ ) shown in figure 4 illustrate the

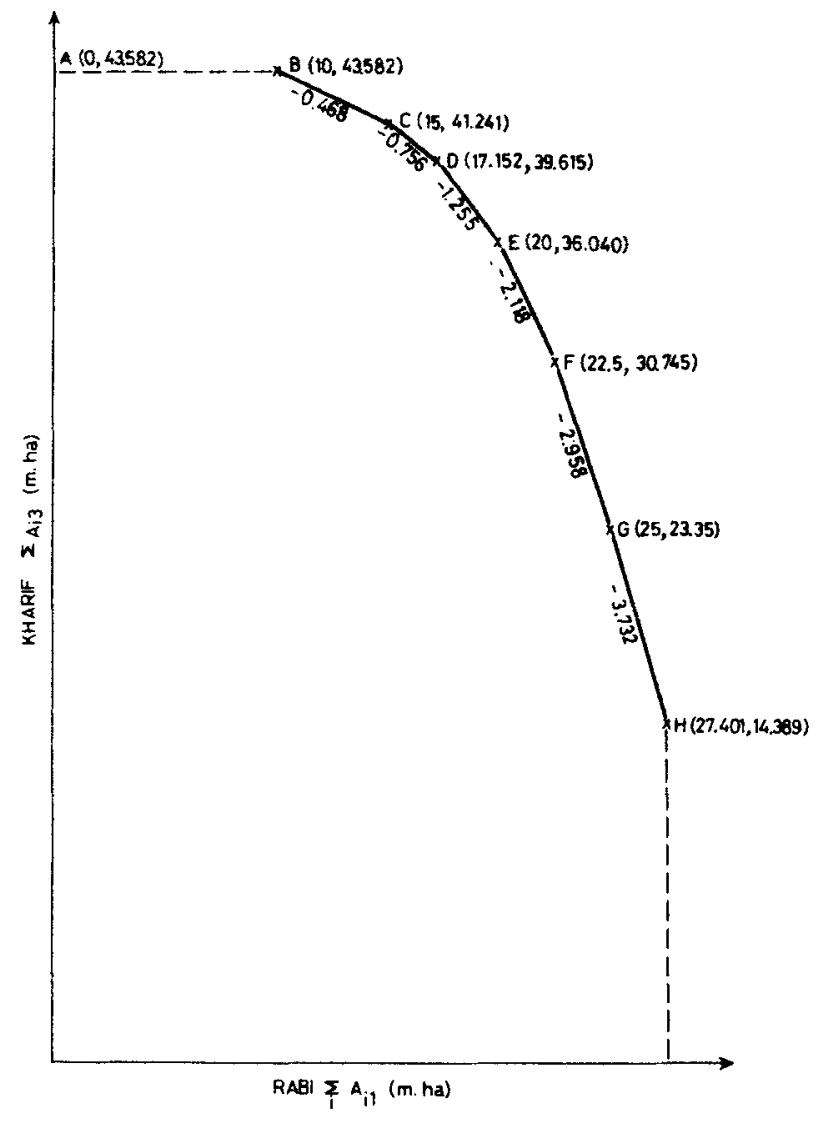

Figure 4. Trade-off between kharif and rabi irrigations 
corresponding irrigation level in the kharif season for each irrigation level in the rabi season. It is not feasible to irrigate in the rabi season at a level higher than $27.4 \mathrm{~m}$ ha. The maximum level of irrigation in kharif can be achieved at a higher level ( $43.6 \mathrm{~m}$ ha). Point $D$ (at which rabi irrigation is $17.2 \mathrm{~m}$ ha and kharif irrigation is $39.6 \mathrm{~m} \mathrm{ha}$ ) represents operating the system for maximum annual total irrigation. Steeper gradients $(-2.96,-3.73)$ at points $E, G$ in figure 4 indicate that 2.96 and 3.73 units of irrigation acreage in kharif season would be given up for every unit increment of irrigation in the rabi season. This is because the June irrigation (summer season) binds the irrigation level of the kharif season $\left(A_{i 2}=A_{i 3}\right)$; therefore, a large quantity of river flow in the kharif season is wasted.

\subsection{Solution 5}

Maximizing energy subject to different levels of rabi and kharif irrigations,

$$
\max Z=f_{P} \cdot \sum_{j} \sum_{i}\left(P_{i j} K_{i}\right)
$$

this solution.is obtained assuming that no new power capacity is provided and energy production must satisfy the demand distributional constraints. For every rabi irrigation level (according to \$5.4) the energy is maximized while increasing kharif irrigation level until infeasibility. To obtain solutions among rabi irrigation, kharif irrigation and the corresponding energy production, the parametric procedure of linear programming is adopted.

\section{Results}

Solutions (rabi irrigation, kharif irrigation and energy production) are presented in table 8 and figure 5. The convex plane $D G H I J K L N^{\prime} E$ represents the operating production frontier. Any point that falls on or inside the feasible region but not on this plane $\left(D G H I J K L N^{\prime} E\right)^{*}$ is not efficient and is dominated by that plane. Point $I$ in figure 5 represents operating the system for agricultural maximization and treating energy production as a residual. Points that fall on the line $D E$ represent operating the system for energy maximization. The rates of marginal transformation are calculated between energy and kharif irrigation for each given rabi irrigation as shown in figure 6 .

The range of variation for energy production as defined in figure 6 is $17,793 \mathrm{GWh}$ $(54,254-36,461 \mathrm{GWh})$ and irrigation acreage has a variation of $15.3 \mathrm{mha}$ $(56.8-41.5 \mathrm{GWh})$. The range of these variations is relatively narrow and no substantial amount of energy will be sacrificed for further agricultural development and vice versa. Basrur (1975) discussed the difficulties of identifying a trade-off between energy and irrigation under the system described in this paper.

At some agricultural districts, June irrigation has bound the following kharif irrigation because less water is available during the summer season.

Reservoirs are used to store the excessive monsoon water to their storage capacities for the irrigation of the following rabi season.

\footnotetext{
* Point $N^{\prime}$ in figure 5 is a linear extrapolation point on the line $E N$ to prevent the production frontier from going to points $M$ and $N$ where the rates of marginal transformation are negligible.
} 
Table 8. Solutions of maximizing energy subject to different levels of $A_{1}$ and $A_{3}$.

\begin{tabular}{|c|c|c|c|c|}
\hline $\begin{array}{l}\text { Point in } \\
\text { figure } 5\end{array}$ & $\begin{array}{c}A_{1} \\
\mathrm{~m} \mathrm{ha}\end{array}$ & $\begin{array}{c}A_{3} \\
\mathrm{~m} \text { ha }\end{array}$ & $\begin{array}{c}A_{1}+A_{3} \\
\mathrm{~m} \text { ha }\end{array}$ & $\begin{array}{c}\text { Energy } \\
\text { GWh }\end{array}$ \\
\hline & 7.5 & $\begin{array}{l}18 \cdot 12 \\
40 \cdot 0 \\
43 \cdot 58\end{array}$ & $\begin{array}{l}25.62 \\
47.5 \\
51.08\end{array}$ & $\begin{array}{l}54254 \\
54254 \\
45443\end{array}$ \\
\hline G & 10 & $\begin{array}{l}15 \cdot 61 \\
40-0 \\
43 \cdot 58\end{array}$ & $\begin{array}{l}25.61 \\
50.0 \\
53.58\end{array}$ & $\begin{array}{l}54254 \\
54254 \\
45443\end{array}$ \\
\hline $\begin{array}{l}D \\
H\end{array}$ & 15 & $\begin{array}{l}11.49 \\
40.0 \\
41.24\end{array}$ & $\begin{array}{l}26 \cdot 49 \\
55 \cdot 0 \\
56 \cdot 24\end{array}$ & $\begin{array}{l}54254 \\
54254 \\
36576\end{array}$ \\
\hline$I$ & $17 \cdot 15$ & $\begin{array}{l}9.89 \\
35.0 \\
39.61\end{array}$ & $\begin{array}{l}27.04 \\
52 \cdot 152 \\
56 \cdot 76\end{array}$ & $\begin{array}{l}54254 \\
54254 \\
36461\end{array}$ \\
\hline $\begin{array}{l}P \\
J\end{array}$ & 20 & $\begin{array}{l}7.8 \\
30.0 \\
35.0 \\
36.04\end{array}$ & $\begin{array}{l}27.8 \\
50.0 \\
55.0 \\
56.04\end{array}$ & $\begin{array}{l}54254 \\
54254 \\
50190 \\
36461\end{array}$ \\
\hline $\begin{array}{l}Q \\
\boldsymbol{K}\end{array}$ & 22.5 & $\begin{array}{l}6.92 \\
25.0 \\
30.0 \\
30-74\end{array}$ & $\begin{array}{l}29.42 \\
47.5 \\
52.5 \\
53.24\end{array}$ & $\begin{array}{l}54254 \\
54254 \\
43592 \\
36461\end{array}$ \\
\hline $\begin{array}{l}E \\
L\end{array}$ & 25 & $\begin{array}{l}6.20 \\
20.0 \\
23 \cdot 35\end{array}$ & $\begin{array}{l}31 \cdot 20 \\
45 \cdot 0 \\
48.35\end{array}$ & $\begin{array}{l}54254 \\
54254 \\
36461\end{array}$ \\
\hline$N$ & 26.09 & 15.44 & $41 \cdot 53$ & 36461 \\
\hline $\begin{array}{l}H \\
K\end{array}$ & $27 \cdot 40$ & $\begin{array}{c}6 \cdot 27 \\
10 \cdot 0 \\
14 \cdot 38\end{array}$ & $\begin{array}{l}33 \cdot 67 \\
37 \cdot 40 \\
41 \cdot 78\end{array}$ & $\begin{array}{l}15200 \\
15200 \\
15152\end{array}$ \\
\hline
\end{tabular}

Power plant capacity and reservoir storage capacity have severely limited the energy production at power plant nodes 37 (Betwa), 41, 42 and 43 (Chambal). At power plant nodes 20 (Rihand) and 30 (Ramganga) the annual hydrological inflows have restricted the energy production.

\subsection{Irrigation level}

(a) The maximum total irrigated acreage (rabi and kharif combined) occurs at point $I$ as shown in figure 5. This irrigation level is $56.8 \mathrm{~m}$ ha $(17.2 \mathrm{~m}$ ha in rabi, and $39.6 \mathrm{~m}$ ha in kharif) and its corresponding energy output is $36,461 \mathrm{GWh}$. Breakdown of annual irrigation level (rabi and kharif, surface water irrigation and groundwater irrigation by states inside India) are presented in tables 9,10 and 11.

At point $I$ in figure 5 , surface water irrigation is 257.2 billion $\mathrm{m}^{3}$ annually $(38.3,29.8$ and 189.1 for rabi, summer and kharif), groundwater irrigation is 122.5 billion $\mathrm{m}^{3}$ (65.1, 43.6 and 13.7 for the respective seasons). Groundwater irrigation in the kharif season is only $11 \%$ of total annual groundwater irrigation while surface water 


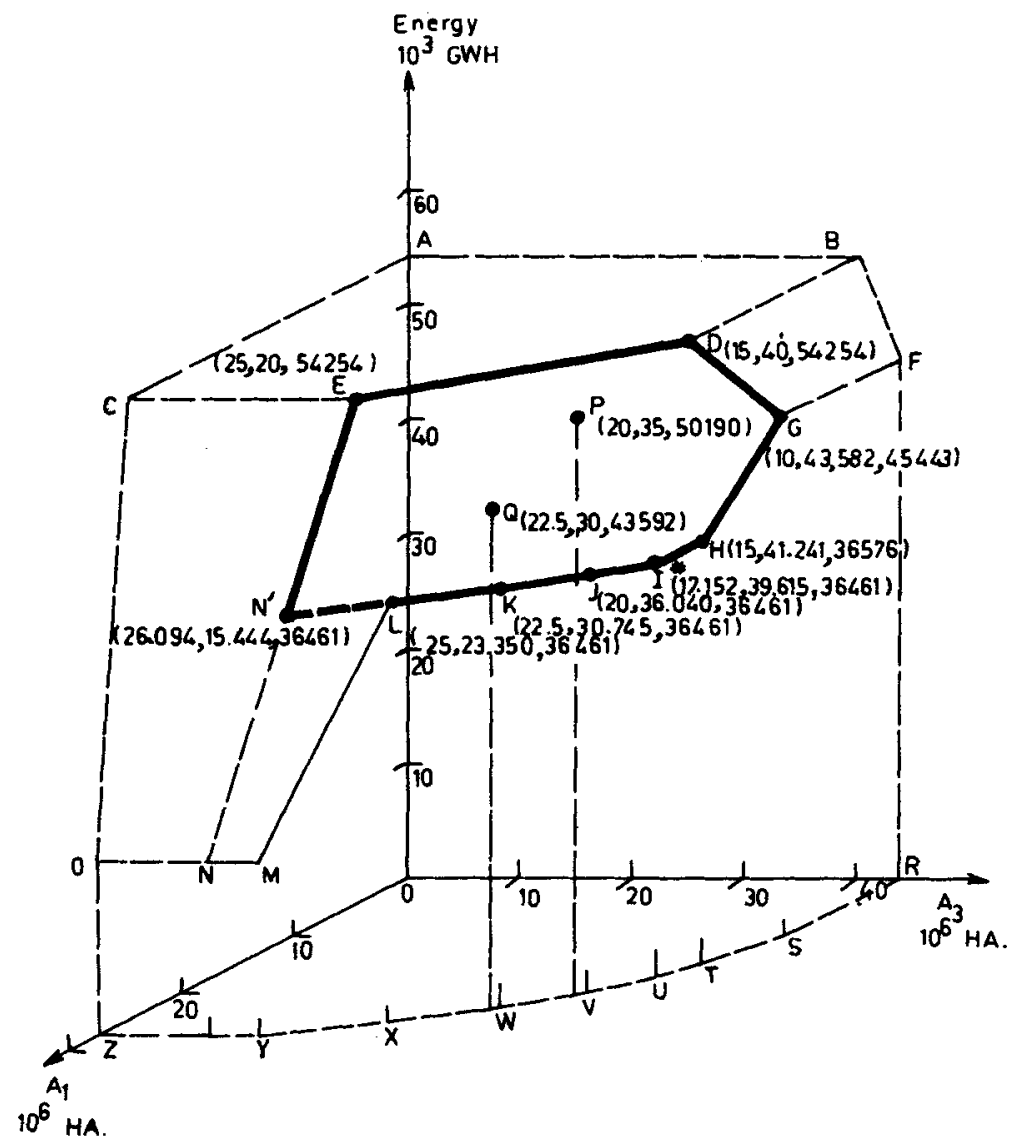

Figure 5. Trade-off among energy, kharif irrigation and rabi irrigation. At point $I, A_{1}$ $=17 \cdot 152, A_{3}=39 \cdot 615$ and energy $=36,461$, where $A_{1}+A_{3}=56,167$ is the maximum irrigated acreage that can be achieved

irrigation is nearly $74 \%$ of the total surface water irrigation. This is because of the monsoon water availability in the kharif season. Surface water and groundwater irrigation relationship is presented in table 12 .

(b) Maximum energy production that satisfies the distributional constraints occurs on the line $D E$ as shown in figure 5 . This energy output is $54,254 \mathrm{GWh}$ and the corresponding irrigation levels are between $45 \mathrm{~m}$ ha and $55 \mathrm{~m}$ ha.

\subsection{Cropping intensity}

The Irrigation Commission (1972) reported that the agricultural level in the Ganges Basin had a net sown area of $43.824 \mathrm{~m} \mathrm{ha}$, a gross sown area of $54.757 \mathrm{~m} \mathrm{ha}$, a net irrigated area of $10.817 \mathrm{~m}$ ha and a gross irrigated area of $12.544 \mathrm{~m}$ ha. Thus, the cropping intensity in 1972 was $125 \%$ and the irrigation intensity was $23 \%$.

The cropping and irrigation intensities in the future according to the above solutions are as follows* (a) The cropping intensity is improved to $148 \%$ when rabi irrigation is

- In order to calculate these intensities, it is assumed that all culturable land is cultivated in the kharif season with or without irrigation and only the area that is irrigated in the rabi season is cultivated in that season. 


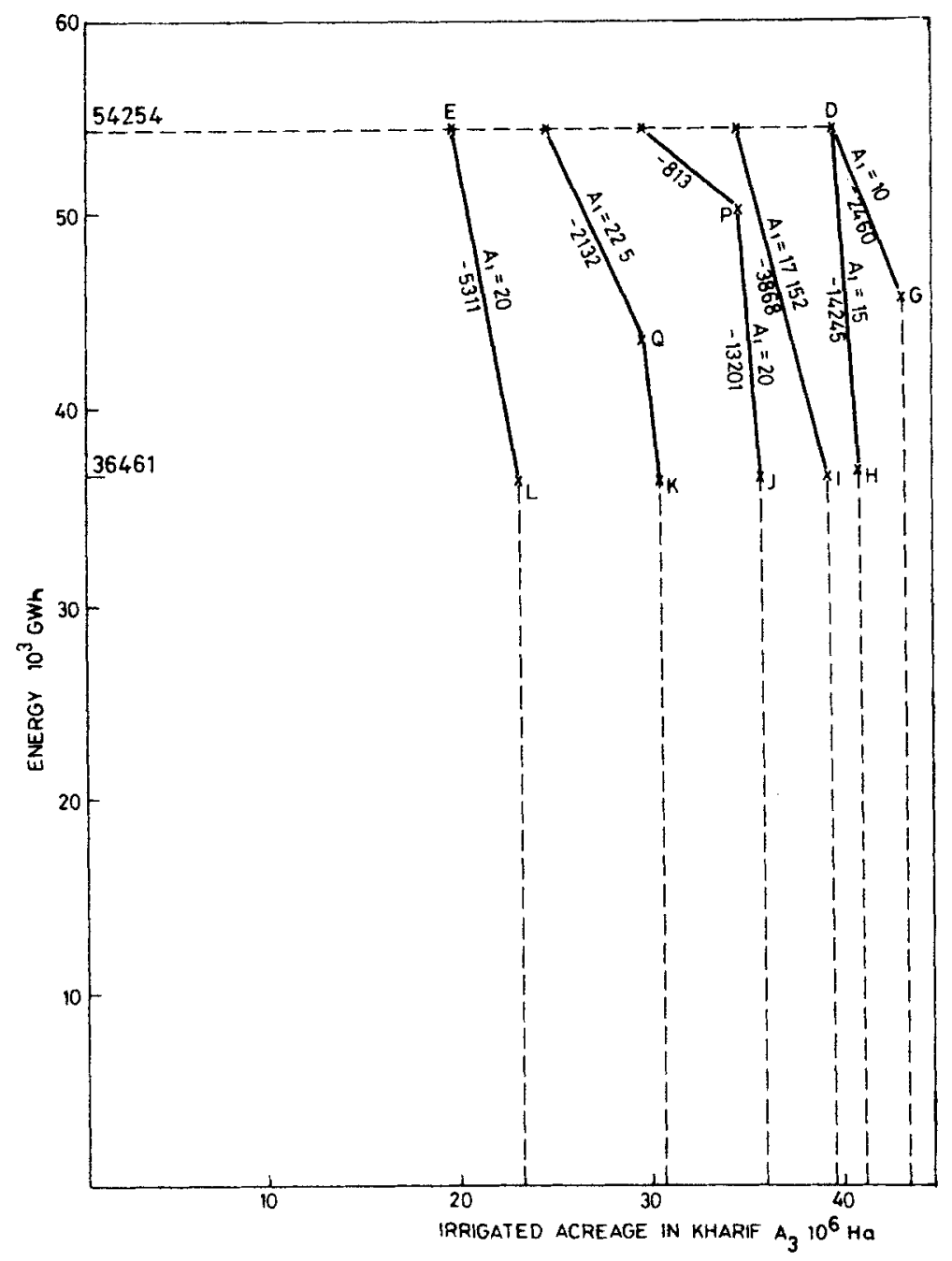

Figure 6. Trade-off among energy, kharif irrigation and rabi irrigation

maximized (point $M$ in figure 5). (b) The cropping intensity is $130 \%$ when the total irrigation is maximized (point $I$ in figure 5).

All the interesting cropping intensities and irrigation intensities from the solutions obtained in this paper can be found in table 13.

\subsection{Degree of complementarity}

It is possible to assess the degree of complementarity of the three-season model by assuming net benefits of energy and irrigation. When these net benefits are absent, ranges of degree of complementarity are obtained.

When the system is operated as a single-purpose one for energy the annual energy production is $54,254 \mathrm{GWh}$; and when the system is operated for agriculture maximization, the annual irrigation level is $56.8 \mathrm{~m}$ ha. Therefore, if the full potential of the 
Table 9. Breakdown of irrigation level between states and seasons

\begin{tabular}{|c|c|c|c|c|c|c|c|c|c|}
\hline Sub-basin & H.P. & Haryana & Delhi & Rajasthan & U.P. & M.P. & Bihar & W.B. & $\begin{array}{c}\text { Total } \\
\text { by basin }\end{array}$ \\
\hline $\begin{array}{ll}\text { Chambal } & A_{1} \\
& A_{3}\end{array}$ & & & & $\begin{array}{l}1.428 \\
1.908\end{array}$ & $\begin{array}{l}0.017 \\
0.022\end{array}$ & $\begin{array}{l}1.087 \\
1.453\end{array}$ & & & $\begin{array}{l}2.532 \\
3.383\end{array}$ \\
\hline Yamuna & $\begin{array}{l}0.018 \\
0.106\end{array}$ & $\begin{array}{l}0.296 \\
1.780\end{array}$ & $\begin{array}{l}0.010 \\
0.061\end{array}$ & $\begin{array}{l}0.243 \\
1.463\end{array}$ & $\begin{array}{l}0.558 \\
3.359\end{array}$ & $\begin{array}{l}0.526 \\
3 \cdot 163\end{array}$ & & & $\begin{array}{l}1.651 \\
9.932\end{array}$ \\
\hline Ramganga & & & & & $\begin{array}{l}1.283 \\
0-471\end{array}$ & & & & $\begin{array}{l}1.283 \\
0.471\end{array}$ \\
\hline $\begin{array}{l}\text { Tons \& } \\
\text { others }\end{array}$ & & & & & $\begin{array}{l}0.071 \\
0.529\end{array}$ & $\begin{array}{l}0.081 \\
0.607\end{array}$ & $\begin{array}{l}0.038 \\
0-284\end{array}$ & & $\begin{array}{l}0.190 \\
1.420\end{array}$ \\
\hline $\begin{array}{l}\text { Gomati \& } \\
\text { Ghaghara }\end{array}$ & & & & & $\begin{array}{l}2 \cdot 260 \\
6.777\end{array}$ & & $\begin{array}{l}0.078 \\
0.233\end{array}$ & & $\begin{array}{l}2 \cdot 338 \\
7.010\end{array}$ \\
\hline Son & & & & & $\begin{array}{l}0.115 \\
0.296\end{array}$ & $\begin{array}{l}0.918 \\
2.279\end{array}$ & $\begin{array}{l}0.417 \\
1.035\end{array}$ & & $\begin{array}{l}1.450 \\
3.600\end{array}$ \\
\hline $\begin{array}{l}\text { Gandak \& } \\
\text { others }\end{array}$ & & & & & $\begin{array}{l}0.083 \\
0.083\end{array}$ & & $\begin{array}{l}3 \cdot 471 \\
3 \cdot 471\end{array}$ & $\begin{array}{l}0.696 \\
0.696\end{array}$ & $\begin{array}{l}4 \cdot 250 \\
4 \cdot 250\end{array}$ \\
\hline $\begin{array}{l}\text { Right bank } \\
\text { tributaries }\end{array}$ & & & & & & & $\begin{array}{l}1 \cdot 195 \\
3 \cdot 191\end{array}$ & $\begin{array}{l}0.837 \\
2.237\end{array}$ & $\begin{array}{l}2.032 \\
5.428\end{array}$ \\
\hline Main Ganga & & & & & $\begin{array}{l}1 \cdot 427 \\
4 \cdot 120\end{array}$ & & & & $\begin{array}{l}1.427 \\
4.120\end{array}$ \\
\hline $\begin{array}{l}\text { Total by } \\
\text { State }\end{array}$ & $\begin{array}{l}0.018 \\
0.106\end{array}$ & $\begin{array}{l}0.296 \\
1.780\end{array}$ & $\begin{array}{l}0.010 \\
0.061\end{array}$ & $\begin{array}{l}1.671 \\
3.71\end{array}$ & $\begin{array}{r}5.814 \\
15.647\end{array}$ & $\begin{array}{l}2.612 \\
7.502\end{array}$ & $\begin{array}{l}5.199 \\
8 \cdot 214\end{array}$ & $\begin{array}{l}1.533 \\
2.933\end{array}$ & $\begin{array}{l}17.153 \\
39.614\end{array}$ \\
\hline
\end{tabular}

Table 10. Annual surface irrigation $\left(10^{9} \mathrm{~m}^{3} /\right.$ year $)$

\begin{tabular}{|c|c|c|c|c|c|c|c|c|c|}
\hline Sub-basin & H.P. & Haryana & Delhi & Rajasthan & U.P. & M.P. & Bihar & W.B. & $\begin{array}{c}\text { Total by } \\
\text { basin }\end{array}$ \\
\hline Chambal & & & & 13.814 & 0.162 & 10.521 & & & 24.497 \\
\hline Yamuna & 0.823 & $13 \cdot 781$ & 0.469 & $11 \cdot 328$ & 26.008 & $24 \cdot 493$ & & & $76 \cdot 902$ \\
\hline Ramganga & & & & & 5.907 & & & & 5.907 \\
\hline $\begin{array}{l}\text { Tons and } \\
\text { others }\end{array}$ & & & & & $2 \cdot 128$ & 2.441 & $1 \cdot 141$ & & 5.710 \\
\hline $\begin{array}{l}\text { Gomati and } \\
\text { Ghaghara }\end{array}$ & & & & & 48.393 & & 1.667 & & $50-060$ \\
\hline Son & & & & & 1.219 & $9 \cdot 707$ & 4.406 & & 15.332 \\
\hline $\begin{array}{l}\text { Gandak and } \\
\text { others }\end{array}$ & & & & & 0.697 & 29.049 & 5.827 & & $35 \cdot 573$ \\
\hline $\begin{array}{l}\text { Right bank } \\
\text { tributaries }\end{array}$ & & & & & & & 7.821 & $5 \cdot 482$ & $13 \cdot 303$ \\
\hline Main Ganga & & & & & 29.959 & & & & 29.959 \\
\hline $\begin{array}{l}\text { Total by } \\
\text { State }\end{array}$ & 0.823 & $13 \cdot 781$ & 0.469 & $25 \cdot 142 \quad 1$ & 114.473 & $76 \cdot 211$ & $20-862$ & $5 \cdot 482$ & 257.243 \\
\hline
\end{tabular}


Table 11. Annual groundwater irrigation $\left(10^{9} \mathrm{~m}^{3} /\right.$ year $)$

\begin{tabular}{|c|c|c|c|c|c|c|c|c|c|}
\hline Sub-basin & H.P. & Haryana & Delhi & Rajasthan & U.P. & M.P. & Bihat & W.B. & $\begin{array}{c}\text { Total by } \\
\text { basin }\end{array}$ \\
\hline Chambal & & & & $13 \cdot 430$ & 0.157 & $10 \cdot 229$ & & & 23.816 \\
\hline Yamuna & 0.175 & 2.937 & 0.100 & 2.414 & 5.543 & $5 \cdot 221$ & & & $16 \cdot 390$ \\
\hline Ramganga & & & & & 3.734 & & & & 3.734 \\
\hline $\begin{array}{l}\text { Tons \& } \\
\text { others }\end{array}$ & & & & & 1.058 & 1.213 & 0.567 & & $2 \cdot 838$ \\
\hline $\begin{array}{l}\text { Gomati \& } \\
\text { Ghaghara }\end{array}$ & & & & & 12.992 & & 0.448 & & 13.440 \\
\hline Son & & & & & 0.976 & 7.774 & 3.529 & & $12 \cdot 280$ \\
\hline $\begin{array}{l}\text { Gandak \& } \\
\text { others }\end{array}$ & & & & & 0.245 & & $10 \cdot 203$ & 2.047 & 12.495 \\
\hline $\begin{array}{l}\text { Right bank } \\
\text { tributaries }\end{array}$ & & & & & & & 15.911 & $11 \cdot 153$ & 27.064 \\
\hline Main Ganga & & & & & $10-454$ & & & & 10.454 \\
\hline $\begin{array}{l}\text { Total by } \\
\text { State }\end{array}$ & 0.175 & 2.937 & 0.100 & 15.844 & $35 \cdot 159$ & 24.437 & 30.658 & $13 \cdot 200$ & 122.510 \\
\hline
\end{tabular}

Table 12. Water utilisation of various solutions

\begin{tabular}{|c|c|c|c|c|c|c|c|}
\hline Point & $\begin{array}{c}\text { Surface } \\
\text { water } \\
10^{9} \mathrm{~m}^{3}\end{array}$ & $\begin{array}{l}\% \text { by } \\
\text { season }\end{array}$ & $\begin{array}{c}\text { Ground- } \\
\text { water } \\
10^{9} \mathrm{~m}^{3}\end{array}$ & $\begin{array}{l}\% \text { by } \\
\text { season }\end{array}$ & $\begin{array}{c}\text { Water } \\
\text { total } \\
10^{9} \mathrm{~m}^{3}\end{array}$ & $\begin{array}{c}\text { Irrigated } \\
\text { acreage } \\
\mathrm{m} \text { ha }\end{array}$ & $\begin{array}{c}\text { Energy } \\
\text { GWh }\end{array}$ \\
\hline \multicolumn{8}{|l|}{ I } \\
\hline rabi & 38.6 & $15 \cdot 0$ & 64.9 & $53 \cdot 0$ & $103 \cdot 5$ & 17.2 & 15.70 \\
\hline summer & 29.5 & 11.5 & 43.9 & 35.8 & $73 \cdot 4$ & - & 7.03 \\
\hline kharif & 189.1 & 73.5 & 13.7 & $11 \cdot 2$ & $202 \cdot 8$ & 39.6 & 13.73 \\
\hline total & 257.2 & 100.0 & 122.5 & $100 \cdot 0$ & $379 \cdot 6$ & 56.8 & 36.46 \\
\hline \multicolumn{8}{|l|}{ D } \\
\hline rabi & 37.5 & $24 \cdot 0$ & 114.5 & $95 \cdot 3$ & 152.0 & 25.0 & $23-36$ \\
\hline summer & 28.0 & 17.9 & $5 \cdot 4$ & $4 \cdot 5$ & $33 \cdot 4$ & - & 10.47 \\
\hline kharif & $90-8$ & 58.1 & 0.2 & 0.2 & 91.0 & 200 & $20-43$ \\
\hline total & $156 \cdot 3$ & $100 \cdot 0$ & $120 \cdot 1$ & $100-0$ & 276.4 & 45.0 & $54 \cdot 26$ \\
\hline \multicolumn{8}{|l|}{$\mathrm{E}$} \\
\hline rabi & $42 \cdot 7$ & $16 \cdot 1$ & $48 \cdot 4$ & $45 \cdot 1$ & 91.0 & $15 \cdot 0$ & $23 \cdot 36$ \\
\hline summer & $33 \cdot 1$ & 12.5 & $41 \cdot 2$ & $38 \cdot 4$ & $74 \cdot 3$ & - & $10-47$ \\
\hline kharif & 188.9 & 71.4 & 17.7 & $16 \cdot 5$ & $206 \cdot 6$ & 400 & 20.43 \\
\hline total & 264.7 & 100.0 & $107 \cdot 3$ & 100.0 & $371 \cdot 9$ & 55.0 & $54 \cdot 26$ \\
\hline \multicolumn{8}{|l|}{$\mathrm{N}$} \\
\hline rabi & $45 \cdot 3$ & 42.4 & $121 \cdot 1$ & 98.8 & $166 \cdot 4$ & 27.4 & 6.55 \\
\hline summer & 15.3 & $14 \cdot 3$ & 1.2 & 1.0 & $16 \cdot 5$ & - & 2.93 \\
\hline kharif & $46 \cdot 4$ & $43 \cdot 3$ & 0.2 & 0.2 & $46 \cdot 6$ & $6 \cdot 3$ & 5.72 \\
\hline total & 107.0 & $100-0$ & 122.5 & $100-0$ & 229.5 & 33.7 & 15.20 \\
\hline \multicolumn{8}{|l|}{$\mathbf{N}^{\prime}$} \\
\hline rabi & 44.0 & $23 \cdot 7$ & $84 \cdot 7$ & 73.8 & $128 \cdot 7$ & $26 \cdot 1$ & 15.70 \\
\hline summer & $24 \cdot 2$ & $13 \cdot 0$ & $21 \cdot 2$ & 18.6 & $45 \cdot 4$ & - & 7.03 \\
\hline kharif & 117.6 & 63.3 & $9 \cdot 0$ & 7.6 & 126.6 & 15.4 & 13.73 \\
\hline total & 185.8 & $100-0$ & 114.9 & $100-0$ & $300-7$ & 41.5 & 36.46 \\
\hline
\end{tabular}


Table 13. Cropping intensities and irrigation intensities in future development

\begin{tabular}{|c|c|c|c|c|c|c|}
\hline Point & $\begin{array}{c}A_{1} \\
\text { m ha }\end{array}$ & $\begin{array}{c}\mathrm{A}_{3} \\
\mathrm{~m} \mathrm{ha}\end{array}$ & $\begin{array}{c}\text { Gross irrigated } \\
\text { area } A_{1}+A_{3} \\
m ~ h a\end{array}$ & $\begin{array}{c}\text { Gross sown } \\
\text { area } A_{1}+57.4^{*}\end{array}$ & $\begin{array}{l}\text { Cropping } \\
\text { intensity }\end{array}$ & $\begin{array}{l}\text { Irrigation } \\
\text { intensity }\end{array}$ \\
\hline $\mathbf{E}$ & 25 & 20 & 45 & $82 \cdot 4$ & 144 & $\$ 5$ \\
\hline D & 15 & 40 & 55 & 72.4 & 126 & 76 \\
\hline G & 10 & 43.6 & 53.6 & $67 \cdot 4$ & 117 & 80 \\
\hline H & 15.4 & $41 \cdot 2$ & 56.6 & 72.8 & 127 & 78 \\
\hline I & 17.2 & 39.6 & 56.8 & 74.6 & 130 & 76 \\
\hline $\mathbf{J}$ & 20 & 36 & 56 & 77.4 & 135 & 72 \\
\hline $\mathbf{K}$ & 22.5 & 30.7 & $53 \cdot 2$ & 79.9 & 139 & 67 \\
\hline $\mathbf{L}$ & 25 & $23 \cdot 4$ & $48 \cdot 4$ & 82.4 & 144 & 59 \\
\hline $\mathbf{M}$ & $27 \cdot 4$ & $14 \cdot 4$ & 41.8 & 84.8 & 148 & 49 \\
\hline $\mathbf{N}^{\prime}$ & 26.1 & $15 \cdot 4$ & $41 \cdot 5$ & 83.5 & 145 & 50 \\
\hline $\mathbf{P}$ & 20 & 35 & 55 & $77 \cdot 4$ & 135 & 71 \\
\hline$Q$ & $22 \cdot 5$ & 30 & 52.5 & 79.9 & 139 & 66 \\
\hline
\end{tabular}

* Assuming all the culturable land is sown during kharif season in future development.

Ganges basin for both energy and agriculture is realized the total benefit would reach $f_{a}$ $56 \cdot 8+f_{P} \cdot 54254$. The degree of complementarity of any solution is:

$$
\frac{f_{a} \sum_{i}\left(A_{i 1}+A_{i 3}\right)+f_{p} \sum_{j} \sum_{i}\left(P_{i j} K_{i}\right)}{f_{a} \cdot 56 \cdot 8+f_{p} \cdot 54254},
$$

and the values for various solutions are given in table 14 .

\section{Summary}

A summary of solutions obtained in this study is presented in table 15. This table lists the objective function, constraint, objective value and remarks for each solution. In each solution, the same hydrological data as shown in tables 2 to 6 are used. This table also indicates the maximum energy production, maximum rabi irrigation and maximum kharif irrigation that can be achieved.

Several solutions are compared with the $\mathbf{1 9 7 2}$ agriculture status in table $\mathbf{1 6 .}$

(i) If the objective is to maximize total irrigation (rabi and kharif) the solution is

Table 14. Degree of complementarity for solutions

\begin{tabular}{llllc}
\hline Point & $\begin{array}{c}\mathbf{A}_{1} \\
(\mathrm{n} \mathrm{ha})\end{array}$ & $\begin{array}{c}\mathbf{A}_{3} \\
(\mathrm{~m} \mathrm{ha})\end{array}$ & $\begin{array}{c}\text { Energy } \\
\text { GWH }\end{array}$ & $\begin{array}{c}\text { Range of degree of } \\
\text { complementarity }\end{array}$ \\
\hline I & $17 \cdot 2$ & 39.6 & 36461 & $0.67-0.99$ \\
D & 15 & 40 & 54254 & $0.97-0.99$ \\
E & 25 & 20 & 54254 & $0.79-0.99$ \\
Points & & & & \\
$\quad$ on DE & $15-25$ & $20-40$ & 54254 & $0-79-0.99$ \\
P & 20 & 35 & 50190 & $0.93-0.97$ \\
Q & 22.5 & 30 & 43592 & $0-80-0.92$ \\
H & 15 & 41.241 & 36576 & $0-69-0.99$ \\
\hline
\end{tabular}


Table 15. Summary of solutions

\begin{tabular}{|c|c|c|c|}
\hline Objective function & Constraints & Objective value & Remarks \\
\hline 1. Maximizing energy & $\begin{array}{l}\text { 1. Basic constraints } \\
\text { (hydrological inputs. ...) } \\
\text { 2. Minimum water supply, } \\
\text { navigation etc. } \\
\text { 3. Minimum flow at Farakka } \\
\text { 4. No new power capacity } \\
\text { 5. No power distributional } \\
\text { constraint. }\end{array}$ & $55,863 \mathrm{GWh}$ & $\begin{array}{l}\text { B } \\
\text { NB } \\
\text { B }\end{array}$ \\
\hline $\begin{array}{l}\text { 2. Maximizing energy } \\
\sum_{j} \sum_{i}\left(P_{i j} \cdot K_{i}\right)\end{array}$ & $\begin{array}{l}\text { 1. Basic constraints } \\
\text { 2. Minimum water supply, } \\
\text { navigation etc. } \\
\text { 3. Minimum flow at Farakka } \\
\text { 4. New power capacity } \\
\text { 5. No power distribution. }\end{array}$ & $103,932 \mathrm{GWh}$ & $\begin{array}{l}\text { NB } \\
\text { NB }\end{array}$ \\
\hline $\begin{array}{l}\text { 3. Maximizing energy } \\
\sum_{j} \sum_{i}\left(P_{i j}, K_{i}\right)\end{array}$ & $\begin{array}{l}\text { 1. Basic constraints } \\
\text { 2. Minimum water supply, } \\
\text { navigation, etc. } \\
\text { 3. Minimum flow at Farakka } \\
\text { 4. No new power capacity } \\
\text { 5. Power distribution } \\
\text { 6. Various levels of } \\
\text { irrigation } \\
\text { ( } 41.8 \text { to } 56.8 \mathrm{~m} \mathrm{ha} \text { ) }\end{array}$ & $\begin{array}{l}\text { from } \\
36,461 \text { to } \\
54,254 \mathrm{GWh}\end{array}$ & $\begin{array}{l}\text { B } \\
\text { B in rabi ceason } \\
\text { B } \\
\text { B } \\
\text { B }\end{array}$ \\
\hline $\begin{array}{l}\text { 4. Maximizing kharif } \\
\text { irrigation }\end{array}$ & $\begin{array}{l}\text { 1. Basic constraints } \\
\text { 2. Minimum water supply, } \\
\text { navigation, etc. } \\
\text { 3. Minimum flow at Farakka } \\
\text { 4. Various levels of } \\
\text { rabi irrigation } \\
\text { (10 to } 27.4 \mathrm{~m} \mathrm{ha})\end{array}$ & $\begin{array}{l}\text { from } \\
14.4 \text { to } 43.6 \mathrm{~m} \mathrm{ha}\end{array}$ & $\begin{array}{l}B \text { in rabi season } \\
B\end{array}$ \\
\hline
\end{tabular}

Table 16. Present (1972) Irrigation and future irrigation (m ba)

\begin{tabular}{|c|c|c|c|c|c|c|}
\hline & (1) & (2) & (3) & (4) & $(5)$ & (6) \\
\hline Rabi & & & 57.42 & $17 \cdot 15$ & 40.27 & 57.42 \\
\hline Summer & & & 57.42 & $39 \cdot 62$ & 17.80 & 57.42 \\
\hline Kharif & & & 57.42 & $39 \cdot 62$ & 17.80 & 57.42 \\
\hline Total ${ }^{*}$ & $12 \cdot 54$ & $102 \cdot 30$ & 114.84 & $56 \cdot 77$ & 58.07 & 114.84 \\
\hline
\end{tabular}

- Total equals rabi plus kharif. (1) Present (1972) gross irrigated area; (2) Present (1972) gross nonirrigated area; (3) Total $=(1)+(2)$; (4) Future area under irrigation; (5) Future area not under irrigation; (6) Total $=(4)+(5)$ 
point $I$ in figure 5. The total irrigation level is $56.8 \mathrm{~m}$ ha which is an improvement of $44.2 \mathrm{~m}$ ha over the 1972 gross irrigation level $(12.5 \mathrm{~m} \mathrm{ha})$ or 2.5 times better.

(ii) If the objective is to maximize rabi irrigation, then point $M$ in figure 5 dominates the other solutions. The total irrigation level is $41.8 \mathrm{~m} \mathrm{ha}(27.4 \mathrm{in} \mathrm{rabi,} 14.4$ in kharif) which is a $29.3 \mathrm{~m}$ ha improvement over 1972 level.

(iii) In order to avoid substantial energy sacrifice when rabi irrigation is maximized, a compromise solution point $N^{\prime}$ in figure 5 is obtained. The total irrigation level is $41.5 \mathrm{~m}$ ha (26.1 in rabi, 15.4 in kharif). This is a $29 \mathrm{~m}$ ha improvement over the 1972 level. In this case, the reduction of rabi irrigation is only $1.3 \mathrm{~m}$ ha from that of case (ii) while the energy output is increased from $15,200 \mathrm{GWh}$ to $36,461 \mathrm{GWh}$.

Since this model of the Ganga basin considers only the benefit to the Indian states it is necessary to understand the water availability when the Ganga enters Bangladesh downstream; River flows at Farakka (which enter Bangladesh) are given in table 17. Values shown in this table are under the maximum irrigation level ( $56.8 \mathrm{~m}$ ha) in Indian states. Table 18 summarizes the results for each of the 9 sub-basins and compares them with the Irrigation Commission (1972) estimates for resource use in 1968-69.

\section{Conclusion}

The objective of this model is to maximize the net benefit of energy and irrigation:

$$
f_{a} \cdot \sum_{i}\left(A_{i 1}+A_{i 3}\right)+f_{p} \cdot \sum_{j} \sum_{i}\left(P_{i j} K_{i}\right)
$$

This objective function has been replaced by a single-purpose objective (either agriculture or energy) in every solution. It either maximizes energy subject to various irrigation levels or vice versa. However, if the net benefits of energy and irrigation are estimated and the objective function

$$
f_{a} \sum_{i}\left(A_{i 1}+A_{i 3}\right)+f_{P} \sum_{j} \sum_{i}\left(P_{i j} K_{i}\right)
$$

is adopted, the solution should fall upon the plane DGHIJKLN'Eas shown in figure 5. Solutions obtained by a comprehensive parametric study on values $f_{a}$ and $f_{p}$ will cover points on the same plane $D G H I J K L N^{\prime} E$ in figure 5.

The model presented in this paper aims to achieve ultimate development for Indian states within the Ganga basin. It is equally important to provide necessary water downstream of the Ganga for optimal development in Bangladesh. This is expressed in the model in the form of minimum irrigation requirements in Bangladesh $\left(X L_{2}\right)$. It is found that the rabi season river flow at Farakka is critical. River flow in this season

Table 17. River flows at Farakka, in Bangladesh, and diversion to Calcutta (million cubic metres)

\begin{tabular}{lccc}
\hline & $\begin{array}{c}\text { River flows at } \\
\text { Farakka }\end{array}$ & $\begin{array}{c}\text { Water available after } \\
\text { Brahmaputra joins Ganga }\end{array}$ & $\begin{array}{c}\text { Diversion to } \\
\text { Calcutta }\end{array}$ \\
\hline Rabi & 500 & 81,061 & 14,680 \\
Summer & 6,580 & 150,471 & 8,808 \\
Kharif & 173,226 & 520,038 & 11,744 \\
\hline Total & 180,306 & 751,570 & 11,744 \\
\hline
\end{tabular}


Table 18. Ganga basin water use and irrigation

\begin{tabular}{|c|c|c|c|c|c|}
\hline Basin & $\begin{array}{l}\text { Average } \\
\text { annual } \\
\text { runoff } \\
\text { (m cu m) }\end{array}$ & $\begin{array}{c}\text { Surface } \\
\text { water } \\
\text { (mcu m) }\end{array}$ & $\begin{array}{l}\text { Ground } \\
\text { water } \\
\text { (m cu m) }\end{array}$ & $\begin{array}{c}\text { Irrigated } \\
\text { areas } \\
\left(\text { ha } \times 10^{6}\right)\end{array}$ & \\
\hline I & 24,312 & $\begin{array}{l}24,497 \\
(8,305)\end{array}$ & $\begin{array}{c}23,816 \\
(5,562)\end{array}$ & $\begin{array}{l}\text { K 3.383 } \\
\text { R 2.532 }\end{array}$ & $(0.886)$ \\
\hline II & 65,621 & $\begin{array}{c}76,902 \\
(15,523)\end{array}$ & $\begin{array}{c}16,390 \\
(9,513)\end{array}$ & $\begin{array}{l}9.932 \\
1.651\end{array}$ & $(3.054)$ \\
\hline III & 18,626 & $\begin{array}{r}5,907 \\
(7,144)\end{array}$ & $\begin{array}{c}3,734 \\
(1,446)\end{array}$ & $\begin{array}{l}0.471 \\
1.283\end{array}$ & $(0-382)$ \\
\hline IV & 14,123 & $\begin{array}{c}5,710 \\
(3,819)\end{array}$ & $\begin{array}{c}2,838 \\
(1,126)\end{array}$ & $\begin{array}{l}1.420 \\
0-190\end{array}$ & $(0-394)$ \\
\hline $\mathrm{v}$ & 122,793 & $\begin{array}{c}50,060 \\
(21,280)\end{array}$ & $\begin{array}{c}13,440 \\
(13,186)\end{array}$ & $\begin{array}{l}7 \cdot 101 \\
2 \cdot 338\end{array}$ & $(2 \cdot 143)$ \\
\hline VI & 42,308 & $\begin{array}{c}15,332 \\
(10,335)\end{array}$ & $\begin{array}{r}12,280 \\
(838)\end{array}$ & $\begin{array}{l}3.600 \\
1.450\end{array}$ & $(0.336)$ \\
\hline VII & 134,277 & $\begin{array}{c}35,573 \\
(26,006)\end{array}$ & $\begin{array}{c}12,495 \\
(1,068)\end{array}$ & $\begin{array}{l}4 \cdot 250 \\
4 \cdot 250\end{array}$ & $(0.374)$ \\
\hline VIII & 45,145 & $\begin{array}{c}13,303 \\
(28,366)\end{array}$ & $\begin{array}{c}27,064 \\
(1,552)\end{array}$ & $\begin{array}{l}5.428 \\
2.032\end{array}$ & (1-872) \\
\hline IX & 42,533 & $\begin{array}{c}29,959 \\
(11,643)\end{array}$ & $\begin{array}{c}10,454 \\
(6,604)\end{array}$ & $\begin{array}{l}4 \cdot 120 \\
1.427\end{array}$ & $(1.914)$ \\
\hline Total & 509,738 & $\begin{array}{c}257,243 \\
(132,421)\end{array}$ & $\begin{array}{l}122,510 \\
(40,895)\end{array}$ & $\begin{array}{l}39 \cdot 614 \\
17 \cdot 153\end{array}$ & $(11 \cdot 36)$ \\
\hline
\end{tabular}

Figures in parentheses represent Irrigation Commission estimates of 1968-69 resource use.

$\left(X_{21}\right)$ is binding at the minimum level. It is important to study the relation between the minimum flow requirement at Farakka and the irrigation level in Indian states.

There are few trade-off points found between energy and irrigation in this threeseason model. This is because under the assumed system no water is diverted for irrigation upstream of a hydropower plant. The same water that drives the turbine can be used to irrigate an agricultural district downstream as discussed by Basrur (1975). The model in its present form considers the Ganga basin within Indian states as a unit despite possible different local interests. If various targets are required by different states in the basin, then more trade-off points can be expected.

Finally, the power conversion factor is estimated according to one half of the dam height. The real energy production will be less than the solutions obtained in this paper. Although seasonal average height of water surface in the reservoir is more appropriate, it is not used in this present study.

It must be clarified as emphasized at the outset that the study brings out only an approach to analysis and the quantitative figures given above are meant only to illustrate the approach for the decomposition of the system and have no real-life implication. However, it must also be added that the systems approach is a powerful tool for planning and if the currently available data with the various governmental agencies were made available, significant improvements in real-life water resources development could be made. This model is only the starting point for a detailed study. 


\section{Appendix A: Mathematics of the Ganga basin model}

The complete Ganga basin model is described in this appendix. In the following algebraic equations, $j$ is an index for month or season $(j=1, \ldots, 12$ for a 12-month model and $j=1, \ldots 3$ for a 3 season model); $i$ is an index for node number $(i=1, \ldots, 49) . I$ is a set that contains the nodes of 25 agricultural districts $2,3,4,5,6,7,12,13,15,16,17,19,24,26,28,29,32,33,35,36,38,40$, 44, 45 and 49.

\section{The constraints}

(i) Hydrological constraints

(a) Continuity constrains

(1) $X_{1 j}=H_{1 j}+X_{2 j}+D_{2 j}$,

(2) $X_{2 j}+Y_{2 j}=X_{3 j}+D_{3 j}-Z_{2 j}$,

(3) $X_{3 j}=X_{4 j}+X_{19, j}+D_{4 j}-Z_{3 j}$,

(4) $X_{4 j}=X_{5 j}+X_{15, j}+D_{15, j}+D_{5 j}-Z_{4 j}$,

(5) $X_{5 j}=X_{6 j}+X_{49, j}+D_{6 j}+D_{49, j}-Z_{5 j}+H_{5 j}$,

(6) $X_{6 j}=X_{7 j}+X_{16, j}+D_{7 j}+D_{16, j}-Z_{6 j}$,

(7) $X_{7 j}=X_{8 j}+X_{17, j}+D_{17, j}-Z_{7 j}+H_{7 j}$,

(8) $X_{8 j}=X_{9 j}+X_{21, j}+H_{8 j}$,

(9) $X_{9 j}=X_{10, j}+X_{28, j}+D_{28, j}+H_{9 j}$,

(10) $X_{10, j}=X_{11, j}+X_{32, j}+D_{32, j}$

(11) $X_{11, j}=X_{12, j}+X_{29, j}+D_{12, j}+D_{29, j}+H_{11, j}$,

(12) $X_{12, j}=X_{13, j}+Y_{29, j}+D_{13, j}-Z_{12, j}$,

(13) $X_{13, j}=X_{14, j}-Z_{13, j}$,

(14) $X_{14, j}=H_{14, j}$,

(15) $X_{15, j}=H_{15, j}-Z_{15, j}$,

(16) $X_{16, j}=H_{16, j}-Z_{16, j}$,

(17) $X_{17, j}=X_{18, j}-Z_{17, j}$,

(18) $X_{18, j}=X_{20, j}+H_{18, j}$,

(19) $X_{19, j}=H_{19, j}-Z_{19, j}$,

(20) $X_{20, j}=P_{20, j}+Y_{20, j}$,

$X_{20, j}=H_{20, j}-\left(V_{20, j}-V_{20, j+1}\right)$,

(21) $X_{21, j}=X_{22, j}+X_{24, j}+D_{24, j}$,

(22) $X_{22, j}+Y_{22, j}=X_{23, j}$,

(23) $X_{23, j}=H_{23, j}$,

(24) $X_{24, j}=X_{25, j}-Z_{24, j}$,

(25) $X_{25, j}=X_{26, j}+Y_{22, j}+D_{26, j}$,

(26) $X_{26, j}=X_{27, j}-Z_{26, j}$,

(27) $X_{27, j}=H_{27, j}$,

(28) $X_{28, j}=H_{28, j}-Z_{28, j}$,

(29) $X_{29, j}+Y_{29, j}=X_{30, j}-Z_{29, j}$,

(30) $X_{30, j}=P_{30, j}+Y_{30, j}$,

$X_{30, j}=H_{30, j}-\left(V_{30, j}-V_{30, j-1}\right)$,

(31) $X_{31, j}=H_{31, j}$, 
(32) $X_{32, j}=X_{35, j}+X_{33, j}+D_{33, j}+D_{35, j}-Z_{32, j}$,

(33) $X_{33, j}=X_{34, j}-Z_{33, j}$,

(34) $X_{34, j}=H_{34, j}$,

(35) $X_{35, j}=X_{36, j}+X_{38, j}+D_{36, j}+D_{38, j}+H_{35, j}-Z_{35, j}$,

(36) $X_{36, j}=X_{37, j}-Z_{36, j}$,

(37) $X_{37, j}=P_{37, j}+Y_{37, j}$,

$X_{37, j}=H_{37, j}-\left(V_{37, j}-V_{37, j-1}\right)$

(38) $X_{38, j}=X_{31, j}+X_{39, j}+H_{38, j}-Z_{38, j}$,

(39) $X_{39, j}=X_{40, j}+X_{44, j}+D_{40, j}+D_{44, j}+H_{39, j}$,

(40) $X_{40, j}=X_{41, j}-Z_{40, j}$,

(41) $X_{41, j}=P_{41, j}+Y_{41, j}$, $X_{41, j}=X_{42, j}$,

(42) $X_{42, j}=P_{42, j}+Y_{42, j}$,

$X_{42, j}=X_{43, j}-\left(V_{42, j}-V_{42, j-1}\right)$,

(43) $X_{43, j}=P_{43, j}+Y_{43, j}$,

$X_{43, j}=H_{43, j}-\left(V_{43, j}-V_{43, j-1}\right)$,

(44) $X_{44, j}=X_{45, j}+D_{45, j}+H_{44, j}-Z_{44, j}$,

(45) $X_{45, j}=X_{46, j}+H_{46, j}-Z_{45, j}$,

(46) $X_{46, j}=X_{47, j}+X_{48, j}$,

(47) $X_{47, j}=H_{47, j}$,

(48) $X_{48, j}=H_{48, j}$,

(49) $X_{49, j}=H_{49, j}-Z_{49, j}$.

(b) Groundwater returns

$$
D_{i j}=\xi_{j}\left[\theta_{i} A G_{i}-\sum_{j} T_{i j}\right] i \in I, \forall_{j}
$$

(ii) Agricultural constraints

(a) Field irrigation requirements

$$
T_{i j}+Z_{i j}=\alpha_{i j} A_{i j}, i \in I, \forall j
$$

(b) Culturable land and current irrigation level

$$
A L_{i} \leqslant A_{i j} \leqslant A H_{i}, i \in I, \forall j
$$

(c) Artificial constraints

$$
A_{i 2}=A_{i 3}, i \in I
$$

(iii) Capacity constraints

(a) Irrigation channels

$$
Z_{i j} \leqslant m_{j}\left(Z H_{i}+Z_{\mathrm{NEW}}\right), i \in I
$$

(b) Groundwater storage

$$
\sum_{i} T_{i j} \leqslant \theta_{i} A G_{i}, i \in I
$$


(c) Diversion channels

$$
Y_{i j} \leqslant m_{j} Y H_{i}, i \in I, \forall j .
$$

(d) Reservoir live storages

$$
V_{i j} \leqslant V H_{i}, \quad i=20,30,37,42,43, \forall_{j}
$$

(e) Hydropower plant capacity

$$
P_{i j} \leqslant m_{j}\left(P_{i}+P_{\mathrm{NEW}_{i}}\right), \quad i=20,30,37,41,42,43, \forall .
$$

(iv) Municipal water supply

$$
Y_{i j} \geqslant m_{j} Y L_{i}, i=2, \forall \text {. }
$$

Diversion to Calcutta for municipal water supply.

(v) Economic constraints

$$
\begin{aligned}
& \sum_{i}\left(P_{i j} K_{i}\right) \geqslant \eta_{i} \sum_{j} \sum_{i}\left(P_{i j} K_{i}\right) \\
& i=20,30,37,41,42,43, \forall j
\end{aligned}
$$

This is the power demand distributional constraint.

(vi) Environmental and other constraints

Minimum river flow

$$
X_{i j} \geqslant m_{j} X L_{i}, i=2,5,7,10,44,45 \forall_{j}
$$

The objective function

The objective of this model is to maximize the net benefit

$$
\begin{aligned}
& \max Z=f\left(f_{a}, A_{i j}, f_{p}, P_{i j}, K_{i} ; f_{a}, f_{P}, K_{i}, i, j\right), \\
& \text { or }=f_{a} \sum_{i}\left[A_{i 1}+A_{i 3}\right]+f_{p} \sum_{j} \sum_{i}\left[P_{i j} K_{i}\right] .
\end{aligned}
$$

\section{Appendix B. Field irrigation requirements}

In this appendix field irrigation requirements $\left(\alpha_{i j}\right)$ in the Ganga basin are examined. Only the Chambal sub-basin (node 40 ) is illustrated because the procedure for obtaining these requirements is similar. The monthly or seasonal field irrigation requirement is a function of (i) evaporation; (ii) cropping pattern; (iii) rainfall and (iv) soil type, conveyance, storage and operational losses.

\section{Evoporation}

Christiansen et al (1966) have developed an empirical formula for estimation of a class A pan evaporation:

$$
E_{p}=0.459 R C_{t} C_{w} C_{h} C_{s} C_{e},
$$


where $E_{p}$ is class $A$ pan evaporation, $R$ is extraterrestrial radiation; $C_{t}, C_{w}, C_{h}, C_{s}$ and $C_{e}$ are coefficients of temperature, wind velocity, relative humidity, sunshine percentage and elevation. These coefficients for node 40 are presented in table B.1.

\section{Cropping pattern}

Evapotranspiration (consumptive use) of a crop is the product of evaporation $\left(E_{p}\right)$ and the consumptive use coefficients $(k)$ of each crop. Consumptive use coefficients of the kharif crop (mainly rice) and the rabi crop (mainly wheat) are taken from Ministry of Agriculture (1971) estimates.

The consumptive use coefficients of rice are $0.97,1.21,1.24$ and 0.80 for the four months of the kharif season July to October respectively. The consumptive use coefficients of wheat are $0.26,0.75,0.90,0.81$ and 0.61 for the months November to March respectively. During the summer season the consumptive use coefficient of 0.8 is assigned to June irrigation for land preparation. There is no irrigation requirement in the months of April and May.

\section{Rainfall}

Net irigation requirements (NIR) are the differences of evapotranspiration and effective rainfall. Effective rainfall depends on the normal rainfall and the consumptive use. These effective rainfalls $\left(R_{e}\right)$ in table B.1 are estimated from Ministry of Agriculture (1971) data.

Table B.1. Field irrigation requirements in Chambal sub-basin (node 40)

\begin{tabular}{lccccccccc}
\hline Month & $R$ & $T_{c}$ & $C_{T}$ & $E_{p}$ & $E_{t}$ & Rainfall & $R_{e}$ & NIR (mm) & FIR (mm) \\
\hline Jan. & 304 & 15 & 0.839 & 119 & 107 & 10.47 & 7.54 & 99 & 132 \\
Feb. & 321 & 19 & 0.965 & 145 & 117 & 7.46 & 5.50 & 111 & 148 \\
Mar. & 422 & 24 & 1.135 & 224 & 137 & 5.83 & 4.60 & 132 & 176 \\
Apr. & 464 & 27.5 & 1.250 & 272 & - & 3.74 & - & - & - \\
May & 513 & 29 & 1.305 & 313 & - & 9.08 & - & - & - \\
Jun. & 507 & 31 & 1.370 & 325 & 260 & 91.42 & 88.68 & 171 & 228 \\
Jul. & 520 & 32.5 & 1.425 & 347 & 337 & 283.42 & 280.00 & 57 & 76 \\
Aug. & 496 & 31 & 1.370 & 318 & 385 & 252.65 & 252.00 & 133 & 177 \\
Sep. & 434 & 29 & 1.305 & 265 & 329 & 137.26 & 137.00 & 192 & 256 \\
Oct. & 381 & 27.5 & 1.250 & 223 & 178 & 19.73 & 17.00 & 161 & 215 \\
Nov. & 309 & 25 & 1.167 & 169 & 44 & 9.30 & 6.00 & 38 & 51 \\
Dec. & 289 & 20 & 1.000 & 135 & 101 & 5.42 & 4.00 & 97 & 129 \\
\hline Total & 4959 & 25.88 & & 2855 & 1995 & 835.78 & 802.32 & 1191 & 1588 \\
& & mean & & & & & & &
\end{tabular}

$R$ radiation in $\mathrm{mm}$ at latitude of $26^{\circ} \mathrm{N} ; T_{\mathrm{c}}$ monthly average temperature in ${ }^{\circ} \mathrm{C} ; C_{T}$ temperature coefficient in Christiansen formula; $E_{p}$ class A pan evaporation (assuming $C_{w} C_{h} C_{s}=1$ ) in mm; $E_{q}$ evapotranspiration (consumption use) in $\mathrm{mm}, E_{q}=k E_{p}$.

Rainfall: monthly rainfall in $\mathrm{mm}$ (weighted average $58 \%$ of East Rajasthan and $42 \%$ of West Madhya Pradesh); $R_{e}$ effective rainfall in $\mathrm{mm} ; \alpha_{40,1}=636 \mathrm{~mm}, \alpha_{40,2}=228 \mathrm{~mm}, \alpha_{40,3}=724 \mathrm{~mm}$.

Node 40 -Latitude $26^{\circ} \mathrm{N}$, Elevation $500 \mathrm{~m}$, Mean temperature $25.88^{\circ} \mathrm{C}$, Annual rainfall $835.78 \mathrm{~mm}$ 
Monthly rainfall of the Chambal sub-basin is a weighted average of East Rajasthan (about $58 \%$ ) and West Madhya Pradesh (42\%). Rainfall statistics of Chambal and other sub-basins are obtained from the Ministry of Irrigation and Power (1972) report.

\section{Losses}

Due to the unavoidable water losses through soil percolation, conveyance, storage and operation, more irrigation water than the estimated net irrigation requirement (NIR) is required. This field irrigation requirement (FIR) is determined by NIR and the field application efficiency (FAC). The efficiency is assumed to include all the losses for simplicity.

$$
\text { FIR }=\text { NIR/FAC. }
$$

An FAC of $75 \%$ is assumed for the Ganga basin model. The field irrigation requirements of Chambal sub-basin are given in the last column (FIR) in table B.1. Thus the FIRS at node 40 for a three-season model are $0.636,0.228$ and 0.724 meters per unit area for the rabi, summer and kharif seasons respectively.

\section{References}

Basrur V 1975 In the search of a trade-off, Harvard University

Biswas A K 1976 Systems approach to water management (New York: McGraw Hill)

Briscoe J 1974 Estimated average monthly flows in sub-basin of Ganges basin, Harvard University

Chaturvedi M C 1974 Ganges basin integrated system studies: Water resources development, Harvard University

Chaturvedi M C 1978 Integrated systems planning for water and energy resources of the Greater Ganga basin (New Delhi: Gandhi Peace Foundation Workshop)

Chaturvedi M C 1979 Regional water resources systems planning-A case study for Punjab (India), III World Congress, IWRA, Mexico City

Chaturvedi M C 1984 Water resources systems planning (New Delhi: Tata McGraw Hill) in press

Chaturvedi M C, Rogers P 1975 Large scale water resources systems planning with reference to Ganges basin, Proc. II World Congress (New Delhi: IWRA)

Chaturvedi M C, Stivastava D K 1981 Water Resources Res. 17: 783-795.

Christiansen J E (1968) J. of irrigation and drainage 94: 243-265.

Hall W A, Dracup J A 1970 Water resource systems engineering (New York: McGraw Hill)

Heimes Y Y 1977 Hierarchial analysis of water resources systems: Modelling and optimisation of large scale systems (New York: McGraw Hill)

Jacoby R D, Loucke D P 1972 Water Resources Res. 8: 1401-1414

Lasdon L 1970 Optimization theory of large systems (London: Macmillan)

Ministry of Agriculture 1971 A guide for estimating irrigation water requirements, Tech. Ser. 2, Water Management Division, Ministry of Agriculture, New Delhi

Ministry of Irrigation and Power 1972 Report of the Irrigation Commission, Government of India, New Delhi

Rogers P \& Chi T V 1973 A coordinating model for the Tiber river basin, Consiglio Nazionale Delli Richerch, Institute di Ricerca Sulla Aque, Reports No. 1 and 6

\section{List of symbols}

$A G_{i} \quad$ area $\left(10^{6} \mathrm{~m}^{2}\right)$ at node $i$ over which groundwater is available

$A H_{i} \quad$ culturable land $\left(10^{6} \mathrm{~m}^{2}\right)$ at district $i$ 
$A L_{i} \quad$ minimum irrigation level (current irrigation level) at district $i$

$D_{i j} \quad$ quantity of water (m cu $m$ ) left from upstream river node $i$ that returns to the river node downstream

$H_{i j} \quad$ hydrological inputs (m cu m) at river node $i$ during $j$ th period

$K_{i} \quad$ power converson factor $(\mathrm{MW} / \mathrm{m} \mathrm{cu} \mathrm{m} / \mathrm{mon})$ at power plant $i$

$m_{j} \quad$ parameter specifying use constraint of a system capacity

$\mathrm{PH}_{i}$ capacity of water (m cu m/mon) driving the turbine at power plant $i$

$P_{i j} \quad$ quantity of water (m cu $\mathrm{m}$ ) driving the turbine at power plant $i$

$P_{\text {NEW }_{i}}$ new capacity (m cu m/mon) to be added at power plant $i$

$T_{i j} \quad$ quantity of groundwater (m cu $\mathrm{m}$ ) pumped for irrigation district $i$ during $j$ th period

$V H_{i} \quad$ capacity (live storage in $\mathrm{mcu} \mathrm{m}$ ) at reservoir $i$

$V_{i j} \quad$ storage (m cu $\mathrm{m}$ ) at reservoir $i$ during $j$ th period

$X_{i j} \quad$ quantity of water in $10^{6} \mathrm{~m}^{3}$ (m cu $\mathrm{m}$ ) flowing through a river away from node $i$ downstream during $j$ th period

$X L_{i} \quad$ minimum monthly flow (m cu m) at node $i$

$Y_{i j} \quad$ quantity of water ( $\mathrm{m}$ cu $\mathrm{m}$ ) diverted from node $i$ in $j$ th period

$Y H_{i} \quad$ capacity of diversion channel from node $i$

$Y L_{i} \quad$ minimum water diversion requirement from node $i$

$Z_{i j} \quad$ quantity of water (m cu $\mathrm{m}$ ) diverted for irrigation from node $i$ during $j$ th period

$\mathrm{ZH}_{i}$ capacity of diversion channel (irrigation) from node $i$

$Z_{N^{\prime}} w_{i}$ new capacity of diversion channel to be added to irrigation

$\alpha_{i j} \quad$ field irrigation requirement $\left(\mathrm{mcu} \mathrm{m} / 10^{6} \times \mathrm{m}^{2}\right)$ at district $i$

$\eta_{j} \quad$ power demand distribution for $j$ th period

$\theta_{i} \quad$ quantity of annual groundwater availability (m cu m/10 $/ 10^{6} \times \mathrm{m}^{2}$ ) at district $i$

$\xi_{j}$ the fraction of total unpumped groundwater returns to river system in $j$ th period 